\title{
Numerical model simulation of the Saharan dust event of 6-11 March 2006 using the Regional Climate Model version 3 (RegCM3)
}

\author{
Carolina Cavazos, ${ }^{1}$ Martin C. Todd, ${ }^{1}$ and Kerstin Schepanski ${ }^{2,3}$ \\ Received 1 September 2008; revised 28 January 2009; accepted 18 March 2009; published 18 June 2009.
}

[1] The Sahara desert is the world's primary source of mineral dust aerosols and is known to be an important but poorly understood component of the climate system. Climate models which incorporate dust modules have the potential to improve our understanding of the climate impacts of dust. In this study, the performance of the Regional Climate Model version 3 (RegCM3) with an active dust scheme is evaluated, using a major dust event of 6-11 March 2006 as a test case. To account for the distribution of preferential dust source regions, soil texture characteristics were modified in dust source regions identified from long-term SEVIRI satellite data. The dust event was associated with a pronounced cold outbreak of midlatitude air over the northern Sahara which produced anomalously strong northerly winds, which propagated from west to east over the Sahara during the study period. This resulted in dust mobilization from multiple dust sources across the domain. RegCM3 represents the space/time structure of near-surface meteorology well, although surface winds are underestimated in absolute terms. The experiment in which soils are modified provides a better representation of local dust sources and emission and resulting atmospheric optical thickness (AOT). In this experiment, model simulated dust flux exported from the Sahara to the Sahel and the tropical east Atlantic is estimated as $1.9 \mathrm{Tg} \mathrm{d}^{-1}$. The dust event had a profound impact on the surface solar radiation budget of $\sim-140 \mathrm{~W} \mathrm{~m}^{-2}$ per unit AOT (domain average). The shortwave radiative effect at the top of the atmosphere is $\sim-10 \mathrm{~W} \mathrm{~m}^{-2}$ per unit AOT over the study domain. However, this is strongly dependent on surface albedo. The results also highlight how errors in model simulated circulation lead to errors in the position of the dust plume.

Citation: Cavazos, C., M. C. Todd, and K. Schepanski (2009), Numerical model simulation of the Saharan dust event of 6-11 March 2006 using the Regional Climate Model version 3 (RegCM3), J. Geophys. Res., 114, D12109, doi:10.1029/2008JD011078.

\section{Introduction}

[2] Mineral dust has a strong influence on the climate system [Forster et al., 2007]. This occurs because dust can affect the radiation budget in different ways: (1) The direct effect on radiative fluxes is related to the capacity of dust to scatter and absorb solar and terrestrial radiation in the atmosphere [Haywood and Boucher, 2000; Miller and Tegen, 1999; Sokolik and Toon, 1996; Tegen et al., 2000]. (2) The indirect effect in which dust aerosols modify the characteristics of clouds and therefore the radiation budget [Penner et al., 1994; Twomey, 1991]. The first indirect effect is the enhancement in the cloud albedo when droplets are formed by mineral dust acting as a cloud condensation nuclei (CCN) [Twomey, 1977]. The second indirect effect is related to an increase in the lifetime of clouds [Albrecht, 1989] and a possible contribution to the suppression of

\footnotetext{
${ }^{1}$ Department of Geography, University College London, London, UK.

${ }^{2}$ Leibniz Institute for Tropospheric Research, Leipzig, Germany.

${ }^{3}$ Leibniz Institute of Marine Sciences at University of Kiel (IFMGEOMAR), Kiel, Germany.
}

Copyright 2009 by the American Geophysical Union. 0148-0227/09/2008JD011078 precipitation [Teller and Levin, 2006]. Kaufman et al. [2005a] observe an increase in cloud fractional coverage and a decrease in effective radius due to dust aerosols over the subtropical Atlantic. Other effects not directly related to the radiative forcing include fertilization of marine and terrestrial ecosystems by dust deposition which results in modification of the Earth's carbon budget [Jickells et al., 2005; Luo et al., 2005; Mahowald et al., 2005; Swap et al., 1992].

[3] As a result of the need to understand and model all key components of the climate system, there has been a growing interest in studying mineral dust aerosols [Sokolik et al., 2001]. In recent years, satellite observations have provided crucial information on dust distribution globally [King et al., 1999], most notably from the Total Ozone Mapping Spectrometer (TOMS) [Herman et al., 1997], Ozone Monitoring Instrument (OMI) [Christopher et al., 2008; Torres et al., 2007], Moderate Resolution Imaging Spectroradiometer (MODIS) [King et al., 1992], the Spinning Enhanced Visible and Infrared Imager (SEVIRI) [Schmetz et al., 2002] and the Multiangle Imaging SpectroRadiometer (MISR) instruments. Estimates of aerosol optical thickness (AOT) from satellite are a primary source of validation data for model 
simulations. Recently, the Cloud-Aerosol Lidar and Infrared Pathfinder Satellite Observations (CALIPSO), offer observations of the three-dimensional distribution of mineral dust. This may improve our understanding of the dust radiative forcing and effect on atmospheric dynamics [Berthier et al., 2006; Grigorov and Kolarov, 2007; Léon et al., 2003]. Ground-based photometer instruments, most notably those in the AERONET (AErosol RObotic NETwork) ground network have provided further information on aerosol loading and optical properties [Dubovik et al., 2000; Holben et al., 1998; Kinne et al., 2003]. These data have been complemented by intensive field campaigns involving in situ surface and aircraft observations. Some relevant field campaigns focused on Saharan dust include the Saharan Dust Experiment (SHADE) campaign [Tanre et al., 2003]; the Puerto Rico Dust Experiment (PRIDE) in July 2000 [Reid et al., 2003], the Bodélé Dust Experiment (BoDEx) in Chad in 2005 [Todd et al., 2007; Washington et al., 2006], the African Monsoon Multidisciplinary Analysis (AMMA) [Redelsperger et al., 2006], and the Saharan Mineral Dust Experiment (SAMUM) (http://samum.tropos.de/).

[4] Ultimately, the study of dust and other aerosols and the climate interaction over the past, present and future requires coupled aerosol-chemistry climate models. Modeling of dust should represent the processes of emission, transport and settling mechanisms and the direct and indirect effects [Tegen, 2003; Tegen and Miller, 1998]. In recent years a number of experimental and operational dust forecasts systems have been developed at institutes around the world, for example, the Navy Aerosol Analysis and Prediction System (NAAPS), at the Dust REgional Atmospheric Model (DREAM) [Nickovic et al., 2001], at the European Centre for Medium-Range Weather Forecasts (ECMWF) [Tompkins et al., 2005] and at the UK Met Office [Greed et al., 2008]. Incorporation of dust in forecasts has been shown to improve forecast accuracy [Perez et al., 2006]. At the same time, inclusion of dust aerosols is an important step in the further development of climate and earth system models. Such dust models can make an important contribution to understanding the role of dust in the climate system. A number of Global Circulation Models (GCMs) now incorporate active dust emission and transport schemes in which dust is a prognostic variable, including the Hadley center models HadCM3 and HadGEM [Bellouin et al., 2008; Woodward, 2001] and the European Centre HAmburg Model (ECHAM5) General Circulation Model [Stier et al., 2005]. In addition there are a number of global off-line chemical tracer models that include dust as a tracer, the Georgia Tech/Goddard Global Ozone Chemistry Aerosol Radiation and Transport (GOCART) model [Ginoux et al., 2001], the global chemical transport model from the Goddard Earth Observing System (GEOSChem) [Bey et al., 2001] and the Dust Entrainment and Deposition (DEAD) model [Zender et al., 2003a]. However, local features such as terrain characteristics and other local atmospheric processes that influences dust production are not well represented in global models because of their coarse resolution. Given the localized nature of many dust sources and the spatial heterogeneity in dust properties, the high spatial resolution of regional climate models (RCMs) can facilitate more accurate simulation of dust aerosolclimate processes. RCMs provide an important test bed for developing and tes erosol processes modules for subsequent incorporation into GCMs [Ghan and Schwartz, 2007]. A number of regional models with dust emission schemes have been developed over the last decade or so including the "Lokal-Model" online-coupled Multiscale Chemistry Aerosol Transport model with a dust emission scheme (LM-MUSCAT-DES) [Heinold et al., 2007], the Regional Climate Model version 3 (RegCM3) [Zakey et al., 2006], the Regional Atmospheric Modeling System (RAMS) [Bouet et al., 2007; Cautenet et al., 2000; Cotton et al., 2003], the DREAM model [Nickovic et al., 2001], and Meso-NH [Grini et al., 2006]. Simulations by both global and regional models can lead to a better understanding of dust processes and their effects on the climate system. At present, however, there exists considerable uncertainty in model estimates of dust emission and fluxes at global [Zender et al., 2004] and regional scales [Todd et al., 2008a; Uno et al., 2006].

[5] This work attempts to (1) determine the ability of the RegCM3 RCM with dust module to simulate dust mobilization over the Sahara desert (in particular, the well known problem of determining dust source regions [Sokolik et al., 2001; Zender et al., 2003b] is addressed); and (2) quantify the climate radiative impact of dust in the region under study. The work focuses on the major Saharan dust event of 6-11 March 2006, described by Slingo et al. [2006], which produced some of the greatest dust emission in the last decade.

\section{Data and Methods}

\subsection{Regional Climate Model (RegCM3) With a Dust} Module

[6] RegCM3 is a hydrostatic, sigma vertical coordinate model similar to the hydrostatic version of the Mesoscale Model (MM5). It was conceived for a wide range of applications at high spatial $(20-80 \mathrm{~km})$ and temporal resolution $(1 \mathrm{~h})$. Examples of the applications of RegCM3 include the evaluation of the interaction between hydrologic and atmospheric processes [Stone et al., 2001], climatic changes due to anthropogenic forcing [Giorgi et al., 2001] and land use [Gao et al., 2003], spatial and temporal variation in precipitation [Ding et al., 2006; Giorgi and Shields, 1999; Seth and Giorgi, 1998], and biomass burning climate effects [Liu, 2005]. The latest model development is the implementation of aerosol modules in an attempt to quantify the climate forcing caused when aerosols are introduced. This scheme allows the simulation of aerosols of anthropogenic origin [Solmon et al., 2006] and those from a natural sources such as mineral dust [Zakey et al., 2006], including processes of emission, transport and deposition.

[7] The processes that control dust emission mechanisms have been described previously by various authors [Alfaro and Gomes, 2001; Marticorena and Bergametti, 1995; Shao, 2000]. Emission is a function of surface characteristics (roughness, soil properties) and wind speed. Dust emissions result from saltation (net horizontal motion of large particles in a turbulent near-surface layer), causing sandblasting of the soil surface and disintegration of saltators which creates a vertical flux of dust into the atmosphere. RegCM3 dust emission is based on work by Alfaro and Gomes [2001] and Marticorena and Bergametti [1995] in which the main steps are: the specification of soil aggregate size distribution for 
Table 1. Summary of RegCM3 Model Configuration

\begin{tabular}{|c|c|}
\hline Characteristic & Description \\
\hline Model name & RegCM3 \\
\hline Reference & Zakey et al. [2006] \\
\hline Boundary conditions & NCEP reanalysis \\
\hline Domain & $25^{\circ} \mathrm{W}-30^{\circ} \mathrm{E}, 0^{\circ}-35^{\circ} \mathrm{N}$ \\
\hline Dust-radiative feedback? & Yes \\
\hline Simulation period & 04-11 March 2006 \\
\hline Horizontal resolution & $40 \mathrm{~km}$ \\
\hline Vertical levels & 23 \\
\hline Height of lowest layer & $40 \mathrm{~m}$ \\
\hline PBL and surface schemes & Holtslag and Boville [1993] \\
\hline Emission scheme ${ }^{\mathrm{a}}$ & $\mathrm{U}^{*^{3}}(\mathrm{MB} 95)$ \\
\hline Land use data & $\begin{array}{l}18 \text { classes on } 1^{\circ} \text { grid based on work } \\
\text { by Matthews [1984] and USGS } \\
\text { (U.S. Geological Survey) }\end{array}$ \\
\hline Surface roughness & One value per land class $(0.1 \mathrm{~m})$ \\
\hline Soil texture data & $\begin{array}{l}12 \text { texture classes based on FAO } \\
\text { [Zobler, 1986] and USDA data } \\
\text { [Dickinson et al., 1993] }\end{array}$ \\
\hline $\begin{array}{l}\text { Soil aggregate } \\
\text { size distribution }\end{array}$ & $\begin{array}{l}\text { 3-mode, lognormal distribution associated } \\
\text { with each texture class }\end{array}$ \\
\hline Soil particle density $\left(\mathrm{g} \mathrm{m}^{3}\right)$ & 2.65 \\
\hline Number of dust bins & $\begin{array}{l}4 \text { size bins for dust transport derived } \\
\text { from } 3 \text { lognormal dust emission modes }\end{array}$ \\
\hline Dust particle size range & $0.1-20 \mu \mathrm{m}$ diameter \\
\hline
\end{tabular}

each model grid cell, the calculation of a threshold wind friction velocity above which wind stress leads to saltation processes, the calculation of the horizontal saltating soil aggregate mass flux, and finally the calculation of the vertical transportable dust particle mass flux generated by the saltating aggregates. For a full description of the equations which parameterize these processes see Zakey et al. [2006] and see Table 1.

[8] For transport, settling and scavenging processes, the tracers are considered as individual components. The tracer transport equation is determined by Solmon et al. [2006]. In this equation, the transport mechanisms (advection, horizontal and vertical turbulent diffusion and convective transport) are represented according to the equation used by Qian et al. [2001]. Other processes included are the wet removal terms by large-scale and convective rain and dry deposition processes.

[9] The soil aggregate size distribution is prescribed from a land surface map with 18 classes of natural land type which is interpolated onto the model grid, including the intensity of cultivation for each grid cell. This classification is a simplification of the classes used to define a wide variety of land surface, hydrological, and vegetation properties. The prescribed soil textures are defined as the percentage of three classes (clay, silt and sand) from the Zobler [1986] assessment of FAO (Food and Agriculture Organization) Soil Units and the USDA (United States Department of Agriculture) data set of soil type, texture, surface slope and other properties. The land surface properties are provided by the Biosphere-Atmosphere Transfer Scheme (BATS) [Yang and Dickinson, 1996], including roughness length, soil moisture and vegetation cover fractions properties that are assigned parameters in the aerosol dust model.

[10] RegCM3 contains a radiative transfer scheme of the National Center for Atmospheric Research (NCAR) Community Climate Model (CCM3) described by Kiehl et al. [1998]. Its predecessor

2) accounted for the effects of
$\mathrm{H}_{2} \mathrm{O}, \mathrm{O}_{3}, \mathrm{O}_{2}, \mathrm{CO}_{2}$. The CCM3 is structured in the same way, but it includes new features such as the effect of additional greenhouse gases $\left(\mathrm{NO}_{2}, \mathrm{CH}_{4}, \mathrm{CFCs}\right)$, atmospheric aerosols, and cloud ice. This latest version of RegCM3 determines the radiative interaction of aerosol tracers over the shortwave solar wavelengths only [Qian and Giorgi, 1999].

\subsection{RegCM3 Model Experiments}

[11] For this analysis, the initial and lateral boundary conditions were extracted from the National Center for Environmental Prediction and the National Center for Atmospheric Research (NCEP/NCAR) Reanalysis Product at $2.5^{\circ} \times 2.5^{\circ}$ resolution. The domain used for this simulation comprises most of North Africa centered on $21^{\circ} \mathrm{N}$ and $2.5^{\circ} \mathrm{E}$, with an horizontal resolution of $40 \mathrm{~km}$ and 23 vertical layers. A summary of the model configurations is shown in Table 1. The area used for the simulation is shown in Figure 1. The model was integrated over the period of 4-11 March 2006. A number of experiments were performed with RegCM3. The nature of these experiments is described in Table 2. It is well known that most dust is emitted from preferential source regions [Prospero et al., 2002; Washington et al., 2003], often related to topographic depressions [Zender et al., 2003b], fluvial sedimentary deposits or paleolake beds. Adequate representation of these sources has often been noted to be a problem for dust models. In EXP2 we utilize a new data source on dust activation developed by Schepanski et al. [2007] (Figure 1) in which active dust sources are identified from satellite imagery from the SEVIRI sensor on board the Meteosat Second generation (MSG) satellite. Schepanski et al. [2007] identified discrete dust plumes using the SEVIRI dust product (see section 2.3) and tracked these back to their source regions from successive 15-min SEVIRI imagery. By analyzing SEVIRI dust product data over the period March 2006 to February 2007 a data set of Dust Source Activation Frequency (DSAF), aggregated on a monthly basis at 1 degree resolution was produced. In EXP2 all model grid cells in which the DSAF is greater than $1 \%$ were prescribed a soil texture class of the sand type. A total of 1587 additional grid cells with $100 \%$ sand were introduced to the default soil map. In both EXP1 and EXP2, dust is radiatively active.

[12] In addition, the sensitivity of the results to the specification of aerosol optical properties is considered. In recent years there has been considerable discussion of the optical properties of mineral dust aerosols with observational studies indicating that dust is less absorbing at visible wavelengths than previously thought [e.g., Kaufman et al., 2001]. The shortwave radiative forcing (RF) sign is determined to a great extent by the Single Scattering Albedo values $(\omega 0)$ and represents the light scattering properties of mineral dust in the atmosphere. In the default configuration of RegCM3 the $\omega$ o values are those defined in the OPAC (Optical Properties of Aerosols and Clouds) database [Hess et al., 1998]. These values are rather lower than some more recent simultaneous remote and in situ observations suggest. According to the latest report of the Intergovernmental Panel of Climate Change (IPCC) [Forster et al., 2007], the single scattering albedo $(\omega 0)$ of pure dust at a wavelength of $0.67 \mu \mathrm{m}$ is predominantly in the range 0.90 to 


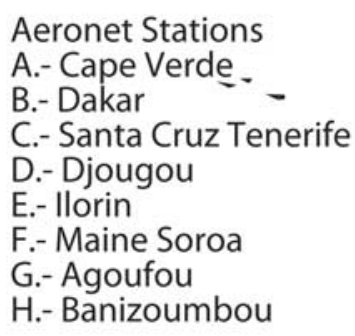

H.-Banizoumbou

WMO Stations
1.- El Oued
2.- Adrar
3.- Illizi
4.- Sebha
5.- Tamanrasset
6.- Bordj Mokhtar
7.- Bilma
8.- Bamako

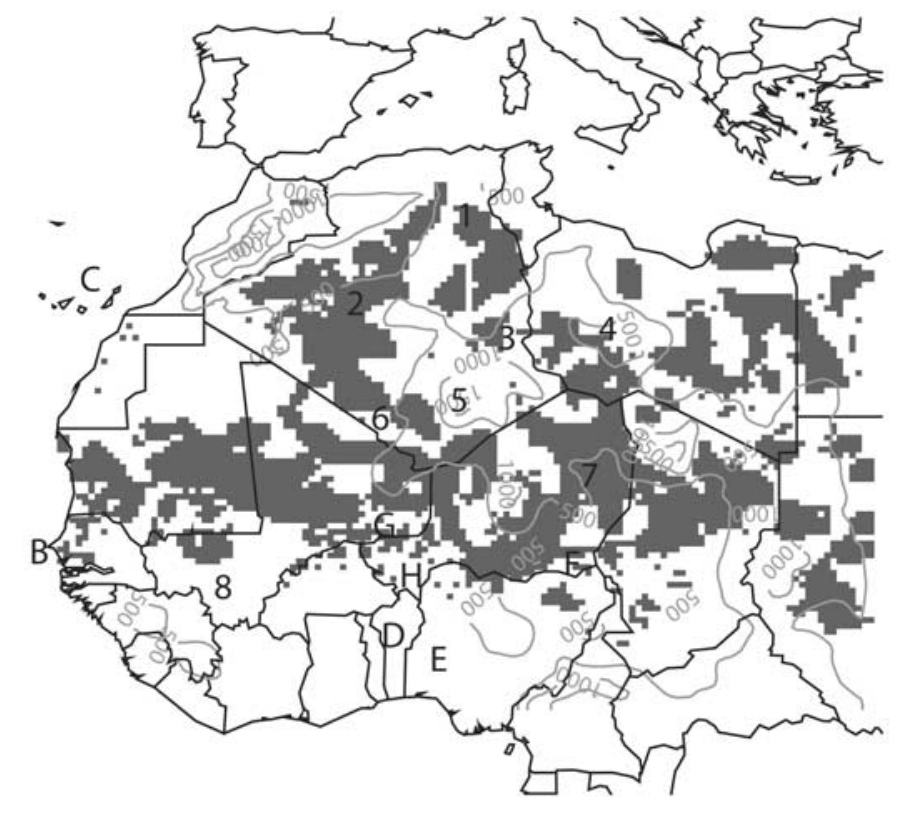

Figure 1. The model study domain. Surface elevation (meters) is represented with contours. Locations of WMO (numbers) and AERONET stations (letters) used in this study are shown. Shading represents the areas where soil texture was adjusted using the method of Schepanski et al. [2007] for EXP2.

0.99, with a central global estimate of 0.96 . To test the sensitivity to $\omega 0$, a further experiment was conducted (EXP2b; see Table 2) identical to EXP2 except that the $\omega 0$ is increased on average +0.02 in the visible wavelengths $(200-700 \mathrm{~nm})$ for each one of the 4 bin sizes and in accordance with the more reflective aerosol type of Helmert et al. [2007].

\subsection{Comparative Data}

[13] Meteorological observations were obtained from a number of WMO stations in the study domain (Figure 1). We selected those stations in the Saharan zone rather than the Sahelian zone farther south as we are primarily interested in model performance in the Saharan dust source regions. The reporting frequency varies between stations. At best the data is hourly although some stations report only at the 0600, 1200 and 1800 local time. Model estimates of near-surface temperature, pressure and wind speed and direction are compared to the observations. Modeled aerosol coefficient extinction at the lowest level (attenuation of the light passing through the near-surface atmosphere due to the scattering and absorption by aerosol particles) is compared to the observations of visibility from WMO stations located in areas near to dust sources. Previous studies have dem- onstrated a good correspondence of visibility and surface extinction at dusty sites [Mahowald et al., 2007].

[14] For validation of model simulated dust emission and transport ground base profiles of AOT at different wavelengths $(440-1020 \mathrm{~nm})$ from Sun photometer measurements from nine AERONET stations located in the RegCM3 domain are used (Figure 1). The spatial distribution of modeled AOT is also compared with a comprehensive set of satellite data sets providing information on atmospheric dust. These consist of the following. First is the European Organization for the Exploitation of Meteorological Satellites (EUMETSAT) dust product color composite from SEVIRI, which is available at 15 min temporal resolution. The Dust Product is generated from the SEVIRI Brightness Temperature Difference (BTD) in three channels located at the infrared $(8.7,10.8,12.0 \mu \mathrm{m})$ [Legrand et al., 2001]. This spectral range allows retrieval of a qualitative dust product even over high-albedo desert surfaces due to spectral different behavior of airborne dust and surface at different wavelengths. Furthermore, measurements in the infrared make night observations possible, although the dust product is more diffuse than during daytime measurements and it is unlikely that dust close to the surface is identified at night. The SEVIRI dust product is a qualitative data set useful to

Table 2. Configuration of Experiments

\begin{tabular}{ll}
\hline Experiment & Description \\
\hline EXP-ND & The no-dust experiment in which the dust module is disabled \\
EXP1 & The dust module is activated and the default soil map is used \\
EXP2 & same as EXP1 except that soil texture is modified to represent preferential \\
& dust source regions. \\
Same as EXP2 but single scattering albedo ( $\omega$ o $)$ is modified as follows \\
(default EXP1 values in parentheses). (1) Wavelength $0.35-0.64 \mu \mathrm{m}, \omega \mathrm{o}=0.96(0.94)$, \\
\\
$\begin{array}{l}0.9(0.88), 0.82(0.80), 0.72(0.70) \text { for } 4 \text { dust size bins } 0.1-1.0,1-2.5,2.5-5,5-20 \mu \mathrm{m} \text { diameter, } \\
\text { respectively. (2) Wavelength } 0.64-0.7 \mu \mathrm{m}, \omega \mathrm{o}=0.99(0.97), 0.91(0.89), 0.88(0.86), 0.77(0.75) \text { for } 4 \text { dust size bins. }\end{array}$
\end{tabular}


identify active dust sources [e.g., Schepanski et al., 2007]. Second are retrievals of the AOT from MISR, which is onboard the National Aeronautic and Space Administration (NASA) Terra spacecraft with a local crossing time of 1030 LT. MISR observes the Earth using nine cameras distributed at different angles in four wavelengths [Bothwell et al., 2002], allowing an appropriate quantification of tropospheric aerosols. The spatial resolution is $\sim 20 \mathrm{~km}$ but the narrow swath limits the temporal resolution to around 1 week such that the spatial coverage is limited. Third are estimates of AOT that were obtained from the qualitative OMI aerosol index (AI) [Torres et al., 1998] using the algorithm proposed by Christopher et al. [2008] based on a comparison of MISR and AI data (we used the regression equation for March from Christopher et al. [2008, Figure 4]). This regression equation was applied OMI AI at $13 \times 24 \mathrm{~km}$ resolution, daily at 1330 local time. However, this relationship is sensitive to biomass burning aerosols and aerosol layer height [Christopher et al., 2008] and in this case the relation results in a low bias in OMI-AOT estimates (see section 3.2). The space/time distribution of satellite AOT is evaluated both to determine mechanisms that contribute to dust emission and transport and analyze the agreement with the modeled dust emission. Model simulated AOT is obtained from integrating the extinction coefficient at 350$640 \mathrm{~nm}$ over the 23 vertical levels.

\section{Results and Discussion}

3.1. Synoptic Conditions During the March 2006 Event

[15] Extreme dust events in many parts of the world are associated with synoptic-scale atmospheric circulation changes. In the Sahara Desert, during winter (October to April), the low-level circulation is dominated by persistent dry northeasterly winds, commonly named Harmattan wind [Kalu, 1979]. The Hamattan is driven by the pressure gradient between the subtropical high (with a mean ridge over Libya) and the equatorial trough (Figure 2a). The spatial structure of northeasterly wind velocity is influenced not only by the large-scale pressure gradients but also locally by pronounced topographic features which act to channel the flow resulting in acceleration, mostly notably to the south of the Tibesti mountains over the Bodélé depression in northern Chad and to the north and south of the Aïr mountains of Niger [Engelstaedter and Washington, 2007; Schepanski et al., 2007; Todd et al., 2008b].

[16] Dust events are relatively infrequent in most parts of North Africa and they occur in winter when the synopticscale circulation results in enhanced low-level winds. The large dust event of 6-11 March 2006 was characterized by rapid anticyclogenesis over the northwest Saharan region associated with an anomalous cold outbreak from the midlatitudes which generated an anomalously strong northerly flow over the region. Recent studies [Milton et al., 2008; Tulet et al., 2008] describe this same large dust event highlighting the intensity of the dust emission, the horizontal and vertical transport and the effect that dust might have itself on atmospheric dynamic. The evolution of phenomena is represented in the Figures $2 b-2 e$. Prior to the start of the dust event on 5 March an intense cyclonic system developed over southern Europe and propagated eastward. By 6 March, the midlatit tmosphere in the European-
Atlantic sector features an anomalous ridge-trough pattern with the trough centered over south-central Europe extending south over Libya (Figure $2 b$ ) and the ridge over the eastern Atlantic, off the Iberian peninsular extending over northwest Africa (Morocco and Algeria). This structure led to an anomalous northerly flow over northern Algeria from 5 March onward. Cold air advection causes large-scale negative temperature anomalies of $\sim 10^{\circ} \mathrm{C}$ over large parts of North Africa, enhancing anticyclogenesis. A striking feature of the atmosphere during this event is the very large ageostrophic component of the wind anomalies. As the midlatitude lowpressure center moved eastward, the ridging high extends southeastward to cover most of the Sahara by 8 March. At this time the northerly low-level wind anomalies are centered over the central Sahara in the Libya-Chad sector. After 9 March the positive pressure and wind anomalies declined.

[17] Synoptic weather station observations clearly depict the characteristics of the cold surge across the Sahara. At most stations the event is evidenced by a (1) pronounced drop in temperature (Figure 3) of up to $10^{\circ} \mathrm{C},(2)$ rapid shift to a northerly wind (Figure 4), (3) wind speed pulse during which time the velocity increases and declines rapidly over a period of about $24 \mathrm{~h}$ (Figure 5), and (4) decline in surface pressure prior to the wind speed maximum followed by an increase typically of about $15 \mathrm{hPa}$ (Figure 6). The southward propagation of the cold surge can be tracked from station to station from the timing of the wind speed maximum (Table 3). For example, the event was detectable over El Oued, northern Algeria at 1800 UTC on 5 March at the southern extremity at Bamako in southern Mali at 0900 UTC on 8 March. In each case the wind speed maximum is coincident with a minimum in observed visibility (Figure 7), indicating a clear association of the wind and dust front features. The wind/dust front is followed by a sustained rise in surface pressure indicating that it occurs at the leading edge of the cold high-pressure surge.

\subsection{Evaluation of Model Simulation}

[18] The model simulates reasonably well many key features of the meteorology. Most notably, the timing of the southward propagating northerly wind burst is well represented with respect to the station observations (Table 3 and Figures 4 and 5). However, a systematic underestimation of wind speeds is evident by up to $50 \%$ in most cases. Todd et al. [2008b] tested the sensitivity of low-level and nearsurface winds in the Bodélé region of northern Chad using the MM5 model and found that simulated winds are most sensitive to the choice of PBL scheme and vertical resolution. It is logical to conclude that the underestimation of LLJ wind speeds in RegCM3 results in part from limitations in the PBL scheme and vertical resolution. Day-to-day temperature anomalies are generally well represented in terms of timing and magnitude (Figure 3). In absolute terms the maximum temperatures are generally to within $\pm 2^{\circ} \mathrm{C}$, but errors in nighttime minima are larger. Notably, overestimated nighttime minima at some locations by up to $5^{\circ} \mathrm{C}$ (e.g., at Bilma) may be a result of an inability to resolve the fine structure of turbulent mixing of heat in the near-surface layers [Todd et al., 2008b]. At other stations there is a slight underestimation of nighttime minima which may be due to the absence of dust aerosol interaction with LW radiative 
a March $1948-2007$ at $925 \mathrm{hPa}$
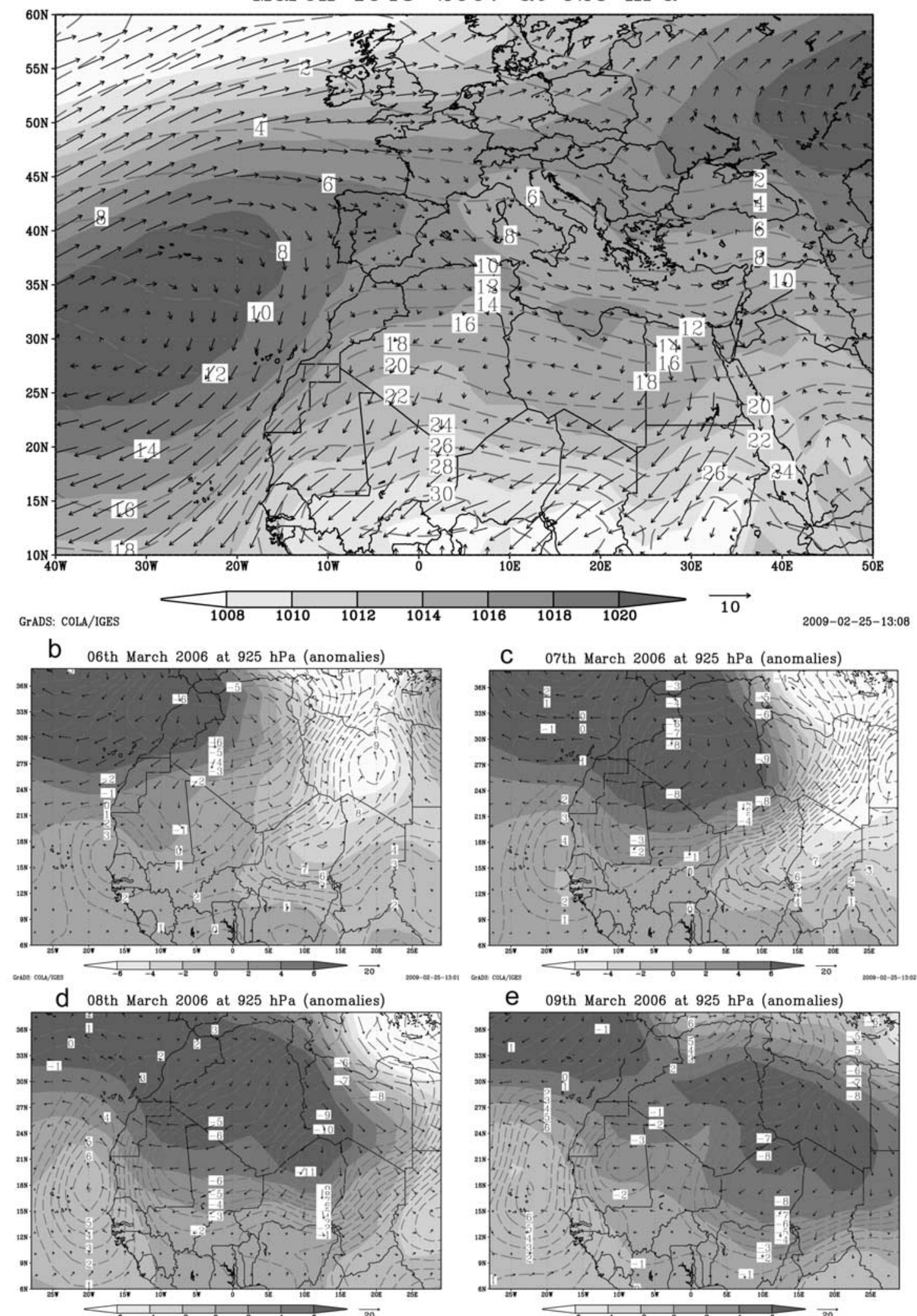

e 09th March 2006 at $925 \mathrm{hPa}$ (anomalies)

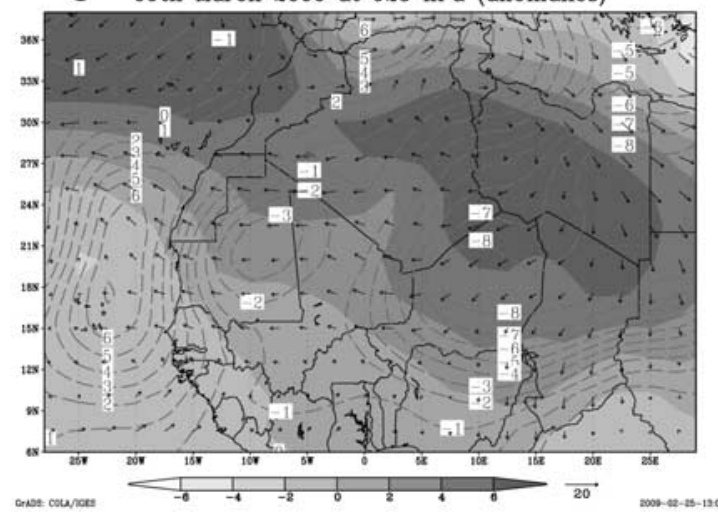

Figure 2. Atmospheric circulation pattern over the model domain, specifically sea level pressure $(\mathrm{mb})$ (shaded) and 925-hpa winds (vectors): (a) long-term mean for March anomalies on (b) 6, (c) 7, (d) 8, and (e) 9 March 2006. Source: NCEP/NCAR Reanalysis Product at $2.5^{\circ} \times 2.5^{\circ}$. 
El Oued $\left(6.12^{\circ} \mathrm{E}, 33.5^{\circ} \mathrm{N}\right)$

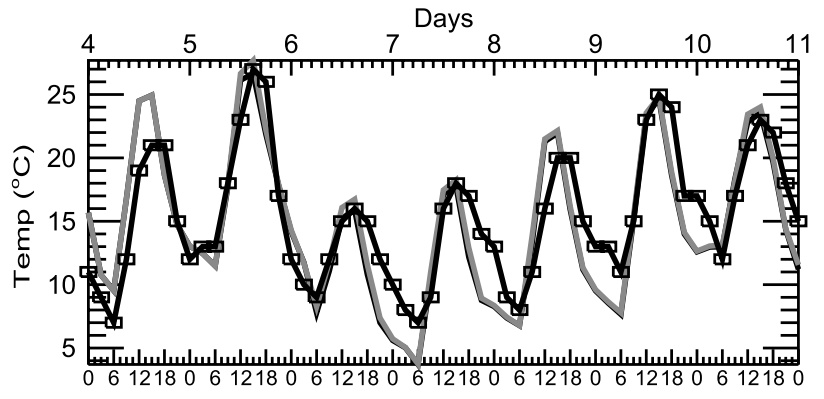

Illizi $\left(8.42^{\circ} \mathrm{E}, 26.5^{\circ} \mathrm{N}\right)$

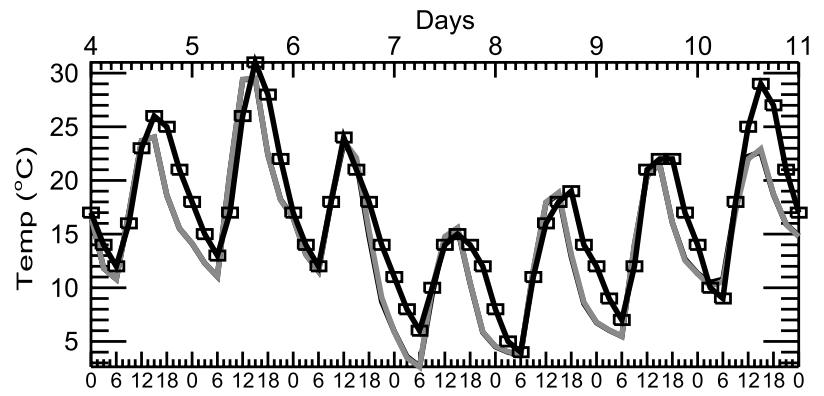

Tamanrasset $\left(5.5^{\circ} \mathrm{E}, 22.8^{\circ} \mathrm{N}\right)$

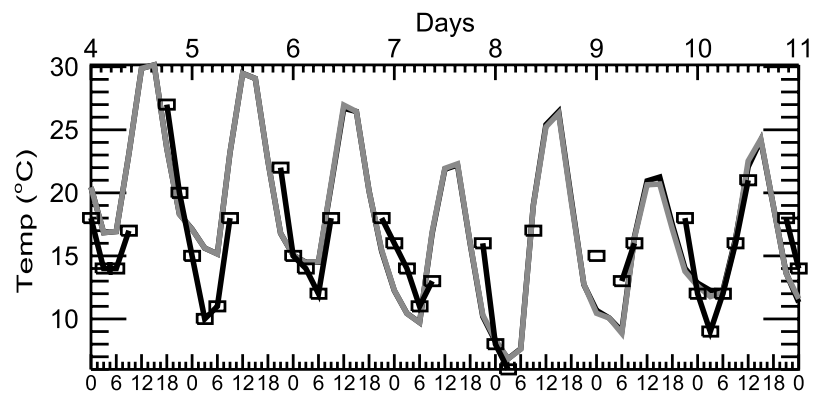

Bilma $\left(12.9^{\circ} \mathrm{E}, 18.7^{\circ} \mathrm{N}\right)$

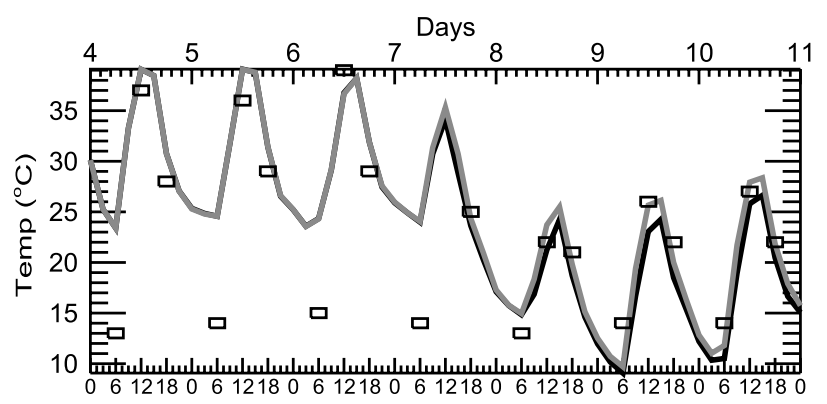

$\operatorname{Adrar}\left(0.3^{\circ} \mathrm{W}, 27.9^{\circ} \mathrm{N}\right)$

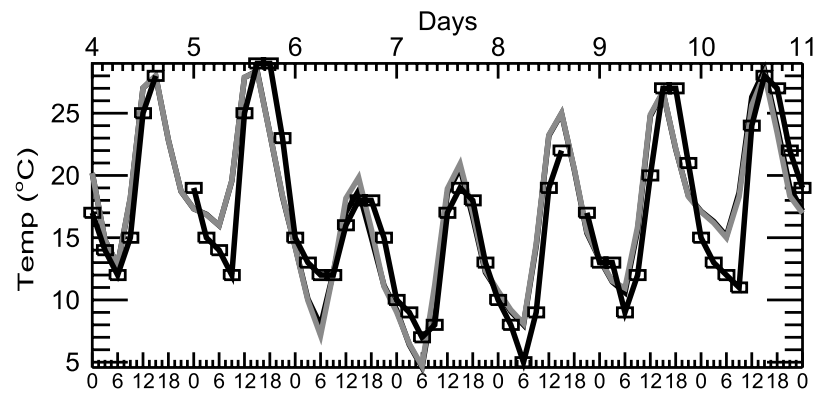

Sebha $\left(14.4^{\circ} \mathrm{E}, 27.0^{\circ} \mathrm{N}\right)$

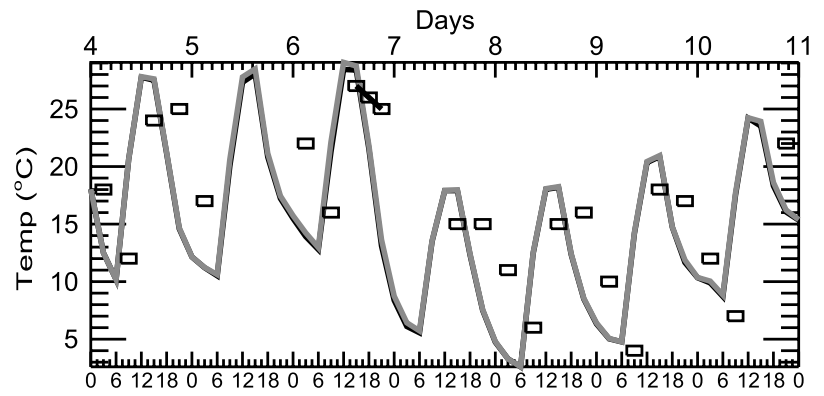

Bordji Mokhtar $\left(0.92^{\circ} \mathrm{E}, 21.38^{\circ} \mathrm{N}\right)$

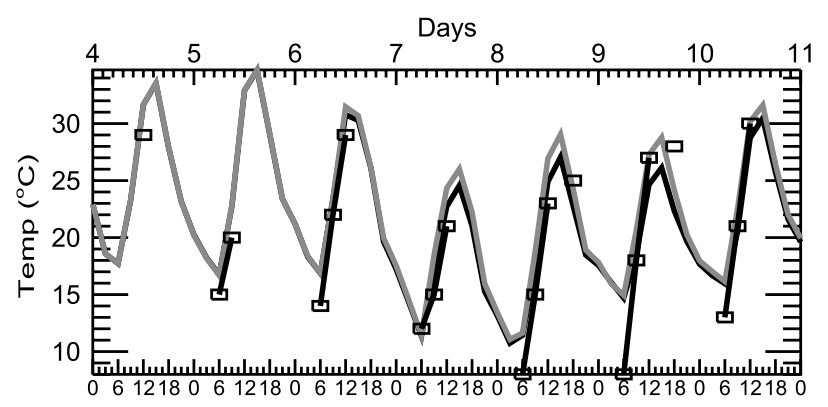

Bamako $\left(7.9^{\circ} \mathrm{W}, 12.5^{\circ} \mathrm{N}\right)$

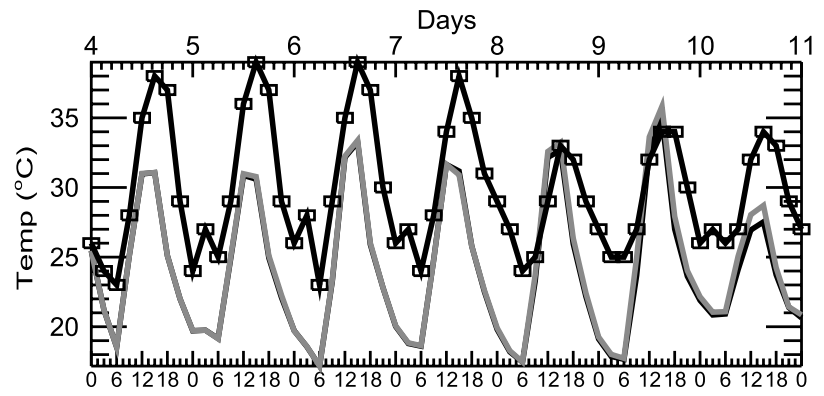

Figure 3. Time series of 2-m temperature $\left({ }^{\circ} \mathrm{C}\right)$ at the location of the WMO stations from observations (squares) and RegCM3 experiments, EXP1 (gray solid curve) and EXP2 (black solid curve).

flux. Overall, however, the model represents the space/time structure of the synoptic forcing reassuringly well even down to local scales.

[19] With regard to dust emission and transport the satellite products show

sive dust mobilization across the Sahara desert during the study associated with the northerly wind outbreak (Figure 8). The dust front is first apparent at the extreme north of the domain over northcentral Algeria at 2100 UTC on 5 March (not shown). The dust front propagates south to extend in a " $V$ " shape across 
El Oued $\left(6.12^{\circ} \mathrm{E}, 33.5^{\circ} \mathrm{N}\right)$

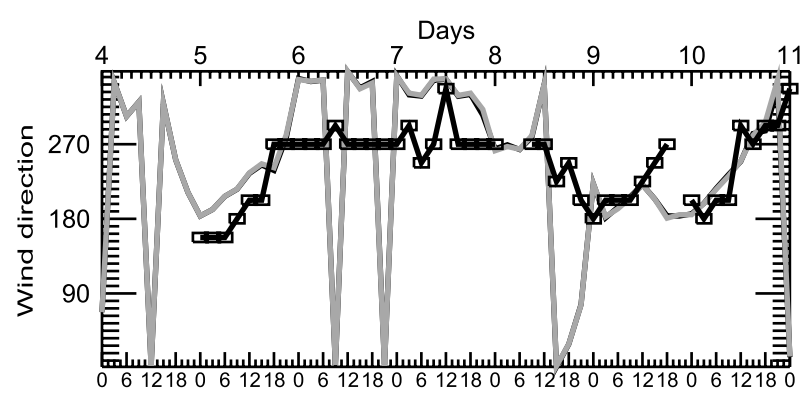

Illizi $\left(8.42^{\circ} \mathrm{E}, 26.5^{\circ} \mathrm{N}\right)$

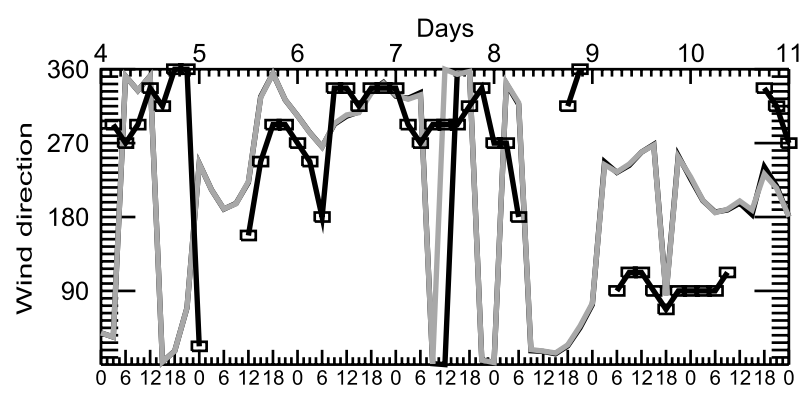

Tamanrasset $\left(5.5^{\circ} \mathrm{E}, 22.8^{\circ} \mathrm{N}\right)$

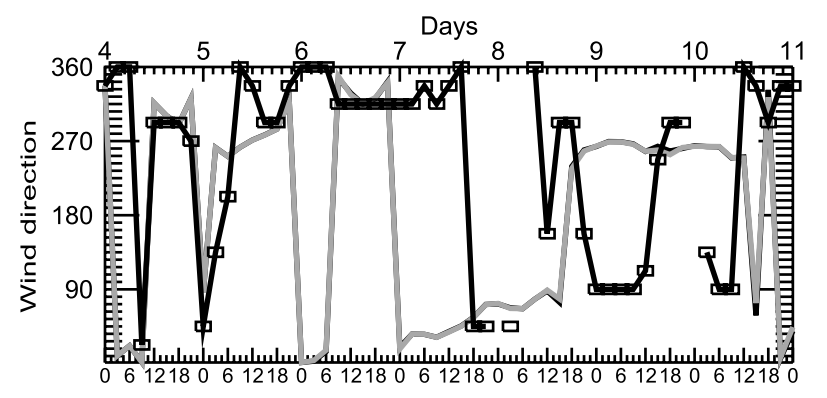

Bilma $\left(12.9^{\circ} \mathrm{E}, 18.7^{\circ} \mathrm{N}\right)$

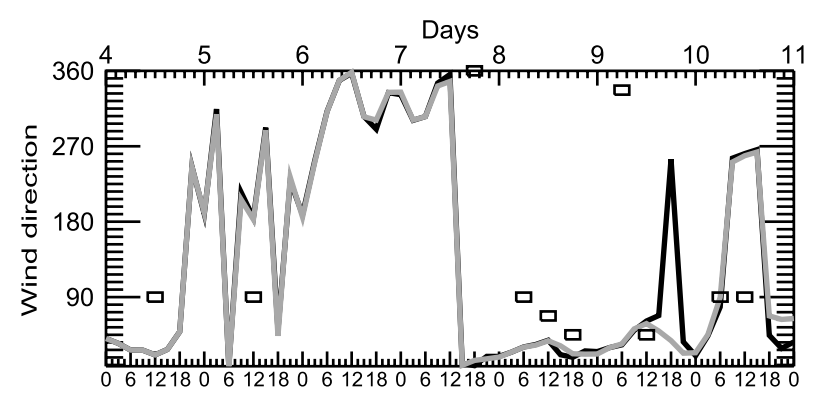

$\operatorname{Adrar}\left(0.3^{\circ} \mathrm{W}, 27.9^{\circ} \mathrm{N}\right)$

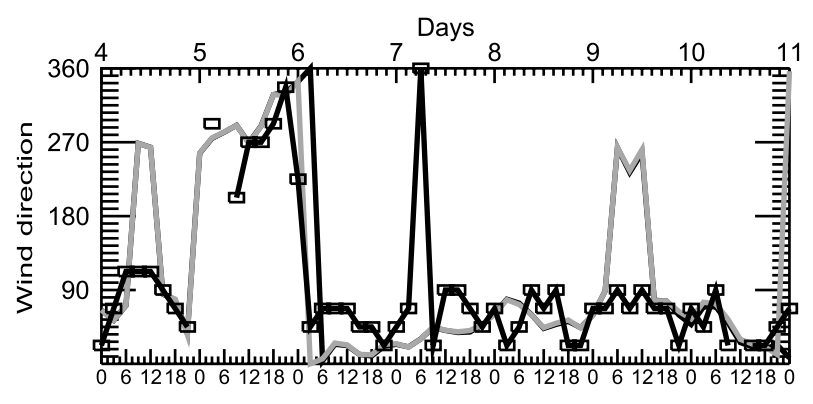

Sebha $\left(14.4^{\circ} \mathrm{E}, 27.0^{\circ} \mathrm{N}\right)$

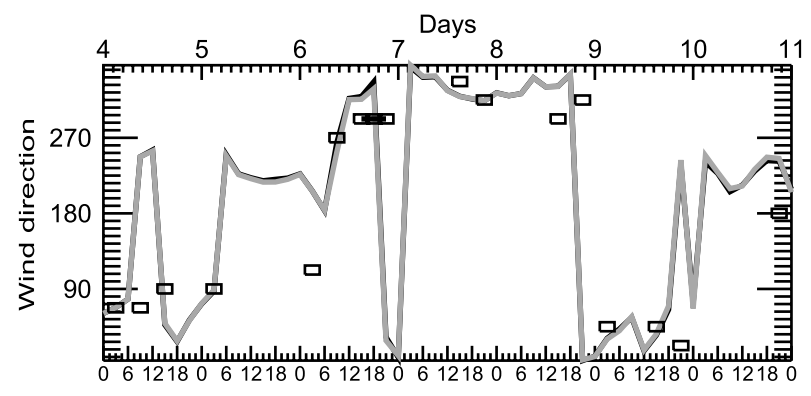

Bordji Mokhtar $\left(0.92^{\circ} \mathrm{E}, 21.38^{\circ} \mathrm{N}\right)$

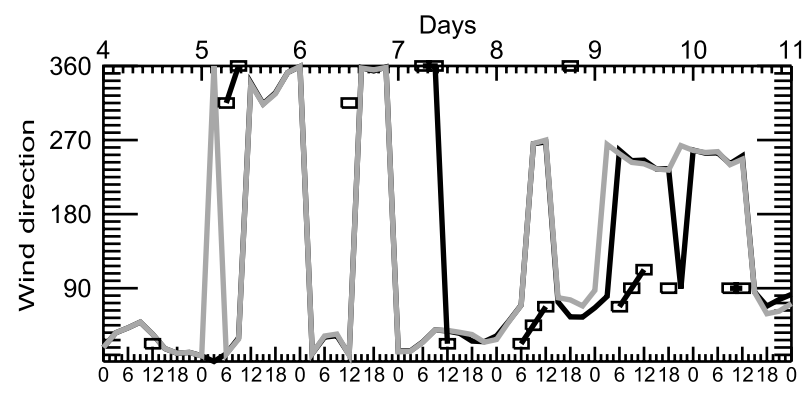

Bamako $\left(7.9^{\circ} \mathrm{W}, 12.5^{\circ} \mathrm{N}\right)$

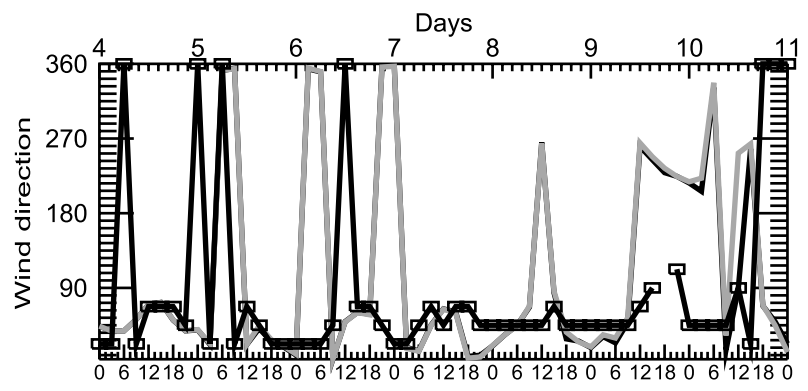

Figure 4. Time series of 10-m wind direction (degrees) at the location of the WMO stations from observations (squares) and RegCM3 experiments, EXP1 (gray solid curve) and EXP2 (black solid curve).

southern Algeria by 1200 UTC on 6 March (feature A in Figure 8a). This structure is partly a result of blocking by the Hoggar mountains. By 1200 UTC on the following day the cold surge and dust plume has propagated south and east, vigorously activating other dust sources, notably on the southwestern flanks on the Hoggar mountains, northern Mali, northwestern Ma ia, the Ténéré desert and the
Tchigai Plateau of northern Niger, immediately to the west of the Tibesti mountains of northern Chad (features $\mathrm{A}-\mathrm{E}$, respectively, in Figure $8 \mathrm{~b}$ ). The dust front has similarities with those activated by density currents generated by evaporative cooling of air over the Atlas mountains documented by Knippertz and Fink [2006]. On 8 March the active sources were located generally east of $5^{\circ} \mathrm{E}$ and were 
El Oued $\left(6.12^{\circ} \mathrm{E}, 33.5^{\circ} \mathrm{N}\right)$

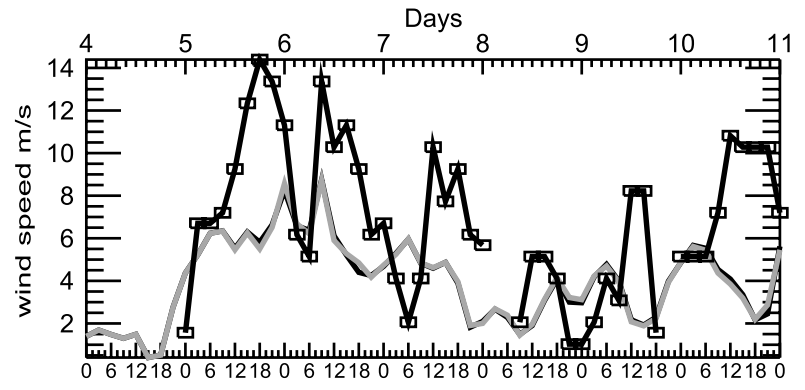

Illizi $\left(8.42^{\circ} \mathrm{E}, 26.5^{\circ} \mathrm{N}\right)$

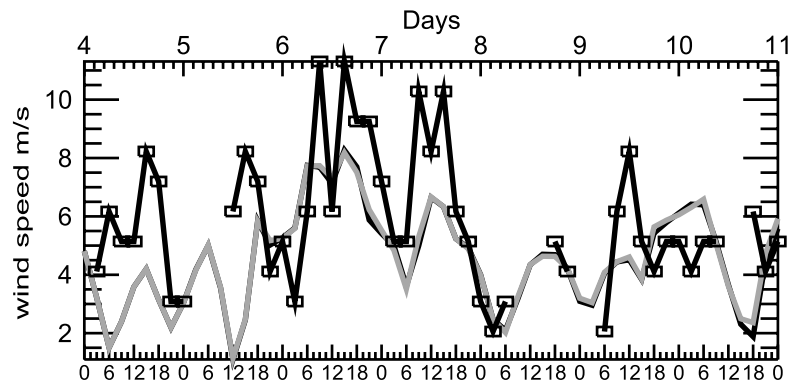

Tamanrasset $\left(5.5^{\circ} \mathrm{E}, 22.8^{\circ} \mathrm{N}\right)$

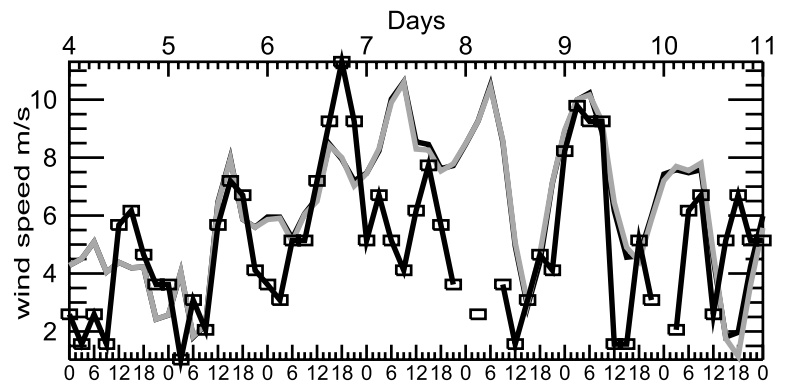

Bilma $\left(12.9^{\circ} \mathrm{E}, 18.7^{\circ} \mathrm{N}\right)$

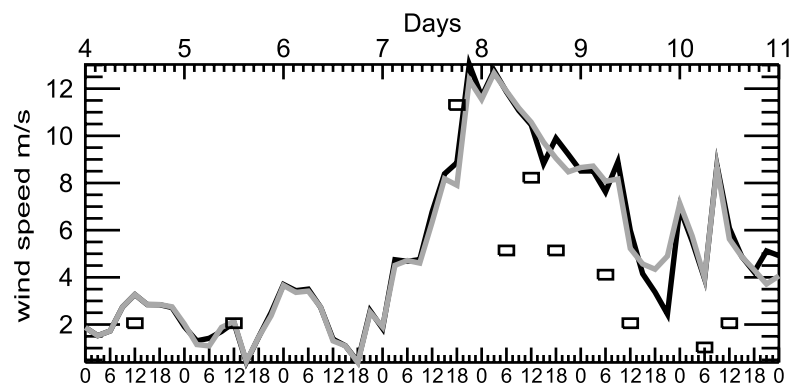

$\operatorname{Adrar}\left(0.3^{\circ} \mathrm{W}, 27.9^{\circ} \mathrm{N}\right)$

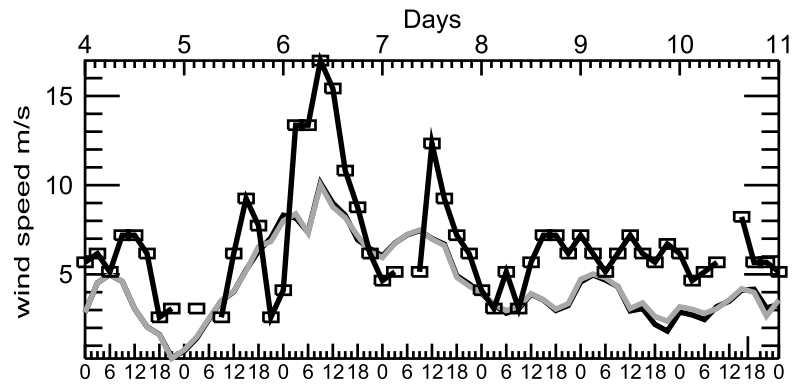

Sebha $\left(14.4^{\circ} \mathrm{E}, 27.0^{\circ} \mathrm{N}\right)$

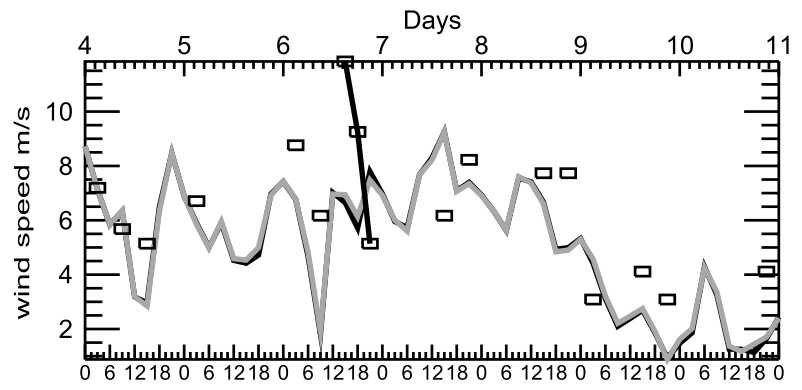

Bordji Mokhtar $\left(0.92^{\circ} \mathrm{E}, 21.38^{\circ} \mathrm{N}\right)$

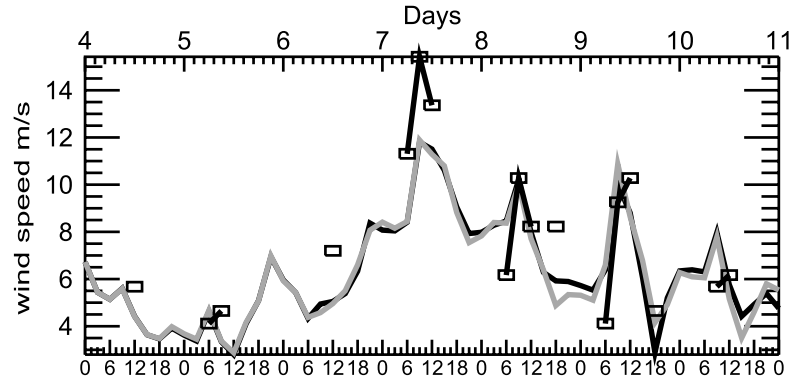

Bamako $\left(7.9^{\circ} \mathrm{W}, 12.5^{\circ} \mathrm{N}\right)$

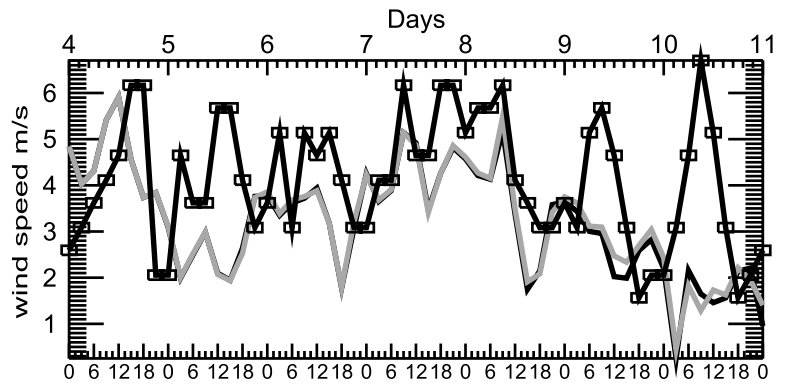

Figure 5. Time series of $10-\mathrm{m}$ wind speed $\left(\mathrm{m} \mathrm{s}^{-1}\right)$ at the location of the WMO stations from observations (squares) and RegCM3 experiments, EXP1 (gray solid curve) and EXP2 (black solid curve).

dominated by sources close to the Algeria-Mali-Niger border point, to the southwest of the Aïr Mountains, the Tchigai plateau and the Tibesti-Ennedi gap of northern Chad, including the Bodélé Depression south of the Tibesti (features A-D, respectively, in Figure 8c). By 9 March strongly active emissio restricted to flanks of the Air mountains and especially the Bodélé Depression region (features A and B, respectively, in Figure 8d). By this time however, dust from the previous days had been transported to the south and west creating a vast plume of dust covering the Sahelian latitudes $\sim 10^{\circ} \mathrm{N}-15^{\circ} \mathrm{N}$ extending from the Atlantic Ocean at $\sim 25^{\circ} \mathrm{W}$ to central Chad at $\sim 20^{\circ} \mathrm{E}$. 
El Oued $\left(6.12^{\circ} \mathrm{E}, 33.5^{\circ} \mathrm{N}\right)$

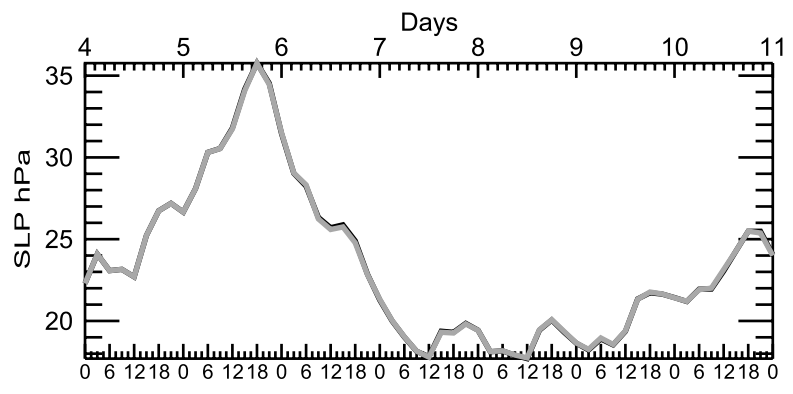

Illizi $\left(8.42^{\circ} \mathrm{E}, 26.5^{\circ} \mathrm{N}\right)$

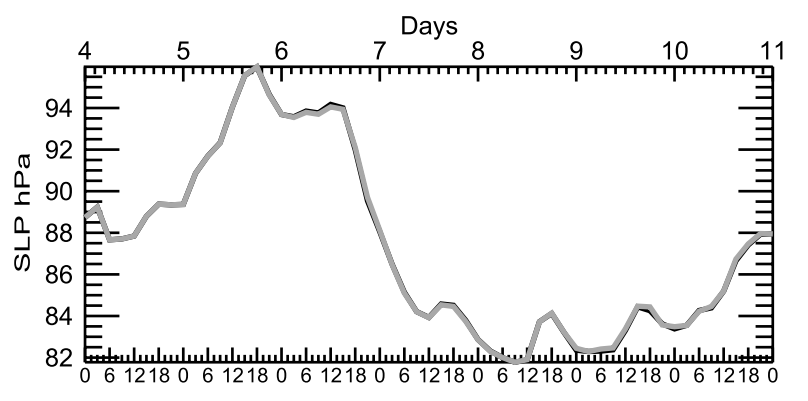

Tamanrasset $\left(5.5^{\circ} \mathrm{E}, 22.8^{\circ} \mathrm{N}\right)$

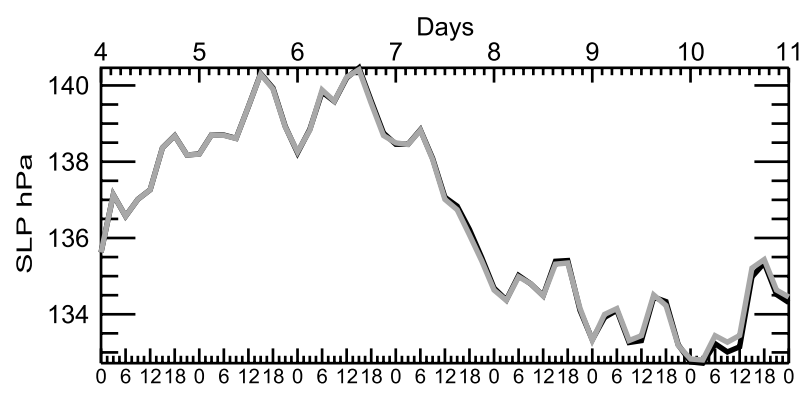

Bilma $\left(12.9^{\circ} \mathrm{E}, 18.7^{\circ} \mathrm{N}\right)$

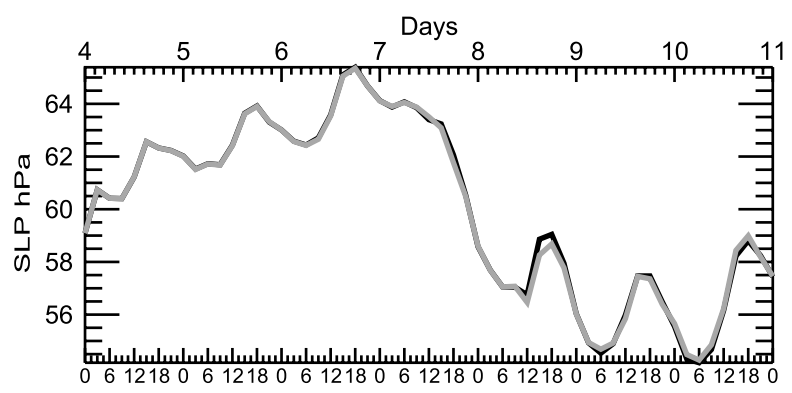

$\operatorname{Adrar}\left(0.3^{\circ} \mathrm{W}, 27.9^{\circ} \mathrm{N}\right)$

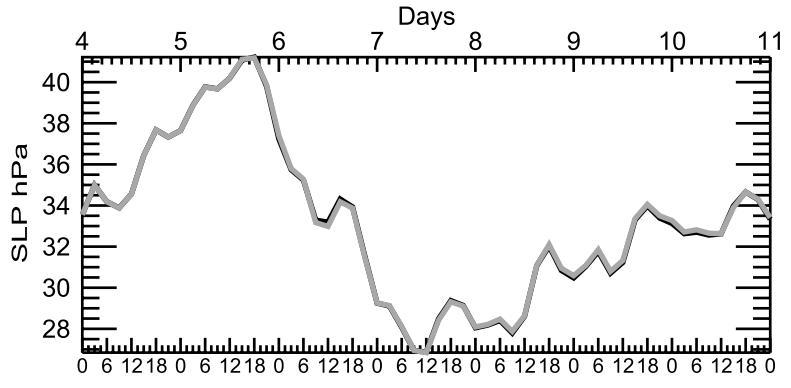

Sebha $\left(14.4^{\circ} \mathrm{E}, 27.0^{\circ} \mathrm{N}\right)$

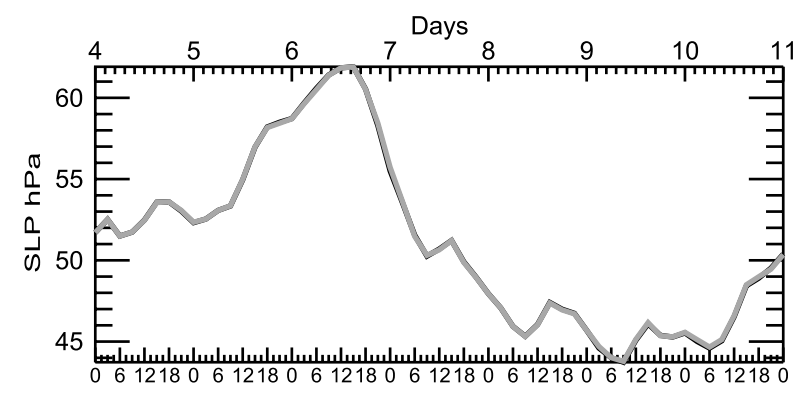

Bordji Mokhtar $\left(0.92^{\circ} \mathrm{E}, 21.38^{\circ} \mathrm{N}\right)$

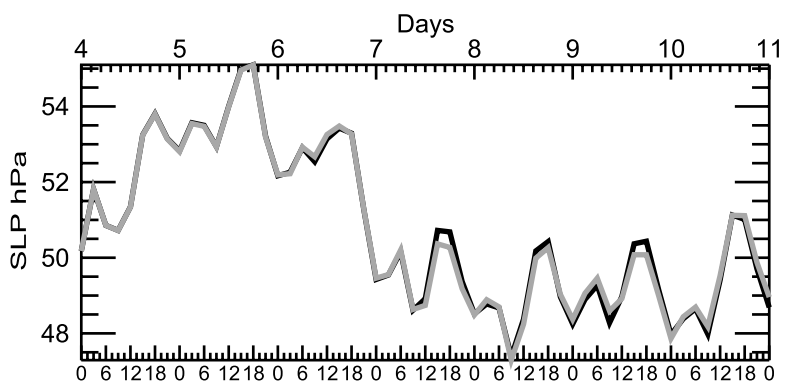

Bamako $\left(7.9^{\circ} \mathrm{W}, 12.5^{\circ} \mathrm{N}\right)$

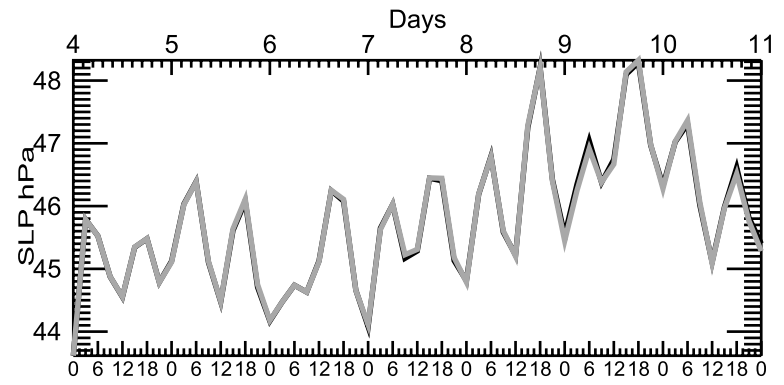

Figure 6. Time series of surface pressure anomalies $(\mathrm{hPa})$, with respect to study period mean from observations at the location of the WMO stations. RegCM3 experiments, EXP1 (gray solid curve) and EXP2 (black solid curve).

Throughout the period of this 4-day dust event the role of topography in modulating dust emission and transport is pronounced. Back-tracking dust plumes in sequential SEVIRI images shows the source regions to be localized and commonly located close to topographic features (Hoggar, Aïr and Tibesti mountains) whe sity is high, providing fine grained fluvial material for deflation. Dust plumes from such sources are transported in topographically constrained low-level jet (LLJ) features most notably the Bodélé LLJ [Todd et al., 2008b; Washington et al., 2006; Washington and Todd, 2005] and the LLJs to the north and south of the Aïr mountains [Schepanski et al., 2007]. 

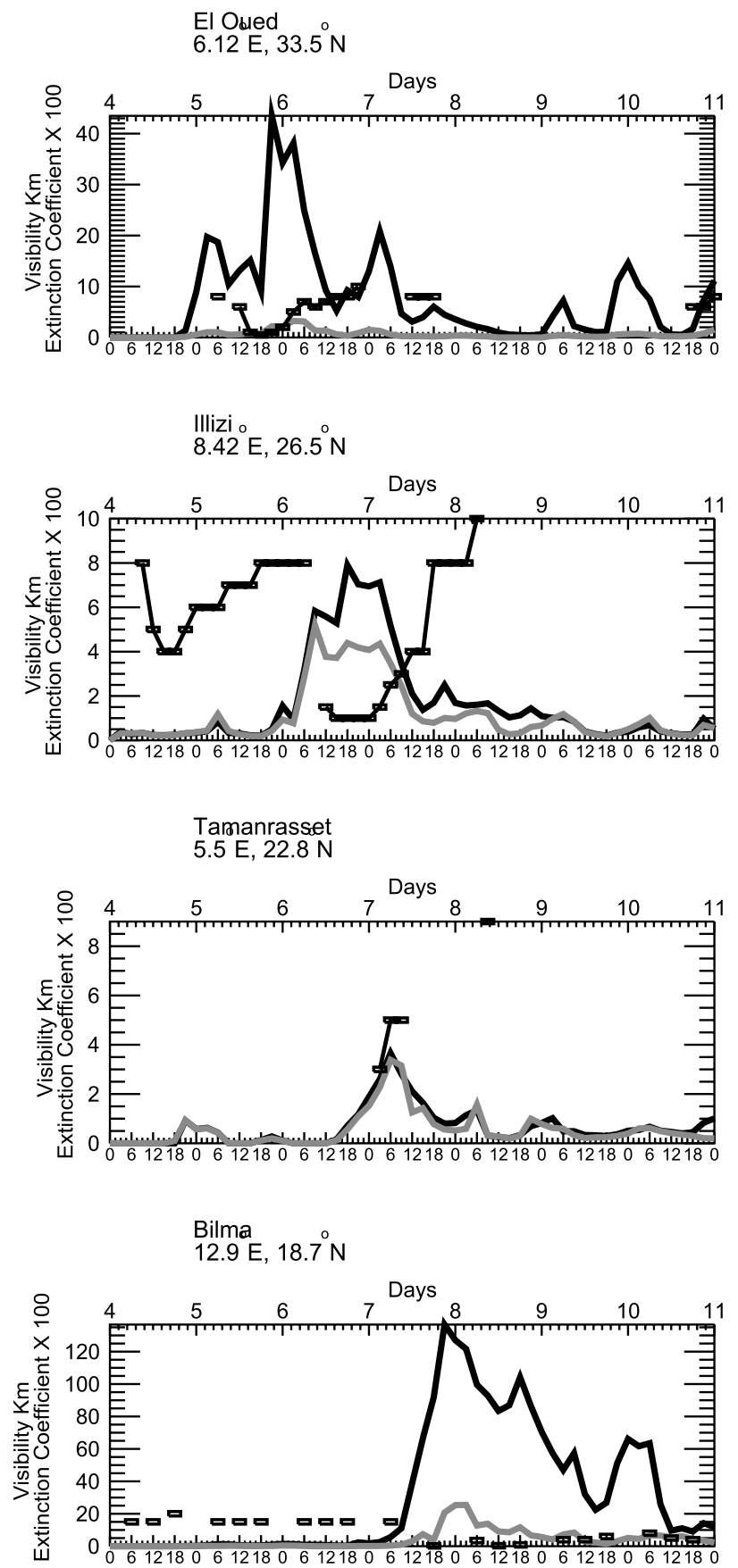
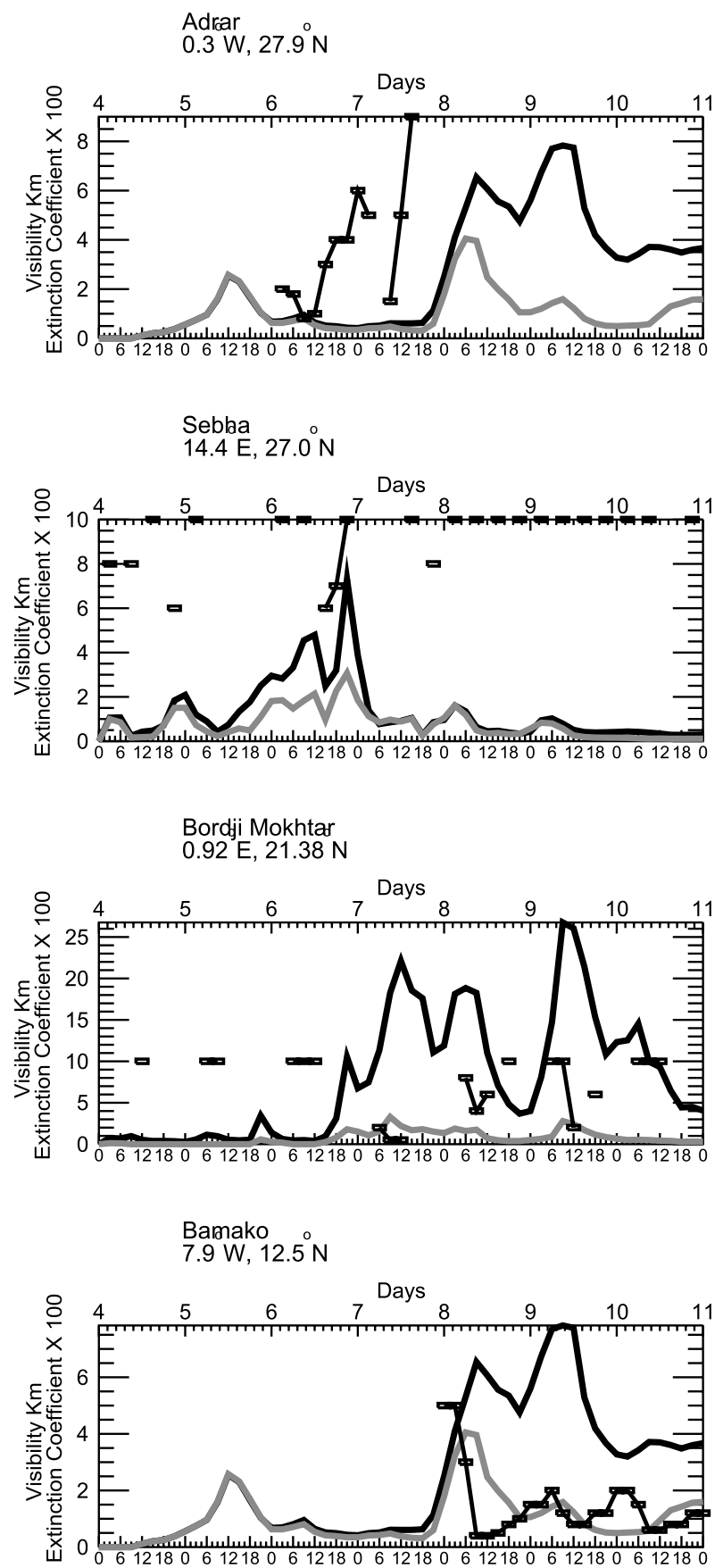

Figure 7. Time series of visibility (kilometers) at the location of the WMO stations from observations (squares) and modeled aerosol extinction coefficient at the lower level from RegCM3 experiments, EXP1 (gray solid curve) and EXP2 (black solid curve). Note inverted scale for visibility.

Table 3. Timing of Near-Surface Wind Speed Maximum

\begin{tabular}{llccc}
\hline WMO Station & Country & \multicolumn{1}{c}{ Location } & $\begin{array}{c}\text { Time (UTC) and } \\
\text { Date of Observed } \\
\text { Wind Maximum }\end{array}$ & $\begin{array}{c}\text { Time (UTC) and } \\
\text { Date of Modeled } \\
\text { Wind Maximum }\end{array}$ \\
\hline El Oued & Algeria & $33^{\circ} 30^{\prime} \mathrm{N}, 06^{\circ} 07^{\prime} \mathrm{E}$ & 18005 March & 09006 March \\
Adrar & Algeria & $27^{\circ} 53^{\prime} \mathrm{N}, 00^{\circ} 17^{\prime} \mathrm{W}$ & 03006 March & 03006 March \\
Illizi & Algeria & $26^{\circ} 30^{\prime} \mathrm{N}, 08^{\circ} 25^{\prime} \mathrm{E}$ & 09006 March & 15006 March \\
Sebhah & Libya & $27^{\circ} 01^{\prime} \mathrm{N}, 14^{\circ} 23^{\prime} \mathrm{E}$ & 12006 March & 15007 March \\
Tamanrasset & Algeria & $22^{\circ} 49^{\prime} \mathrm{N}, 05^{\circ} 28^{\prime} \mathrm{E}$ & 18006 March & 09007 March \\
Bordj Mokhtar & Algeria & $21^{\circ} 22^{\prime} \mathrm{N}, 00^{\circ} 55^{\prime} \mathrm{E}$ & 09007 March & 09007 March \\
Bilma & Niger & $18^{\circ} 41^{\prime} \mathrm{N}, 12^{\circ} 55^{\prime} \mathrm{E}$ & 18007 March & 06008 March \\
Bamako & Mali & $12^{\circ} 32^{\prime} \mathrm{N}, 07^{\circ} 57^{\prime} \mathrm{W}$ & 09008 March & 09008 March
\end{tabular}


a)

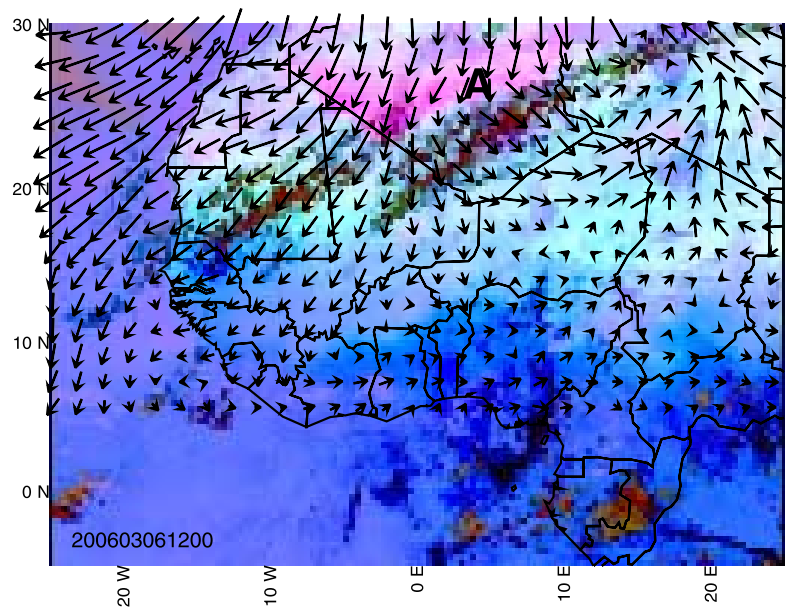

c)

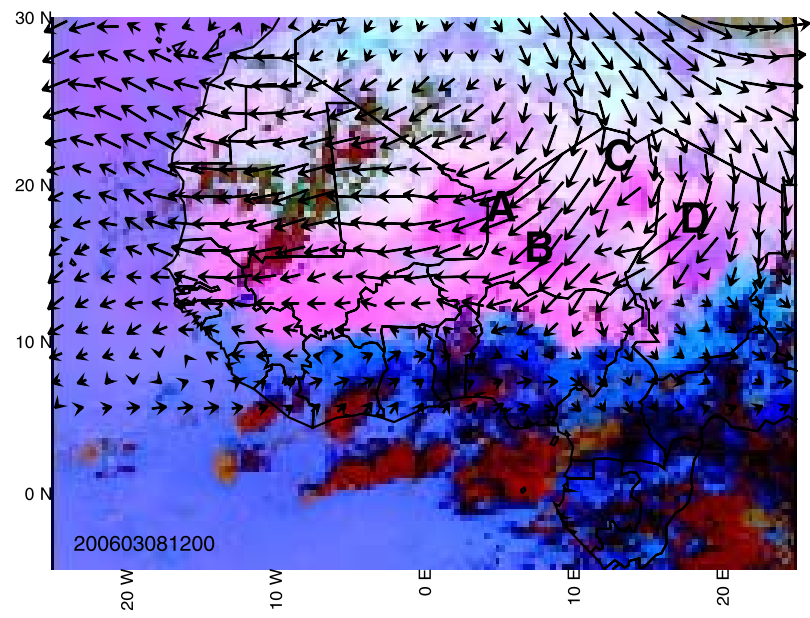

b)

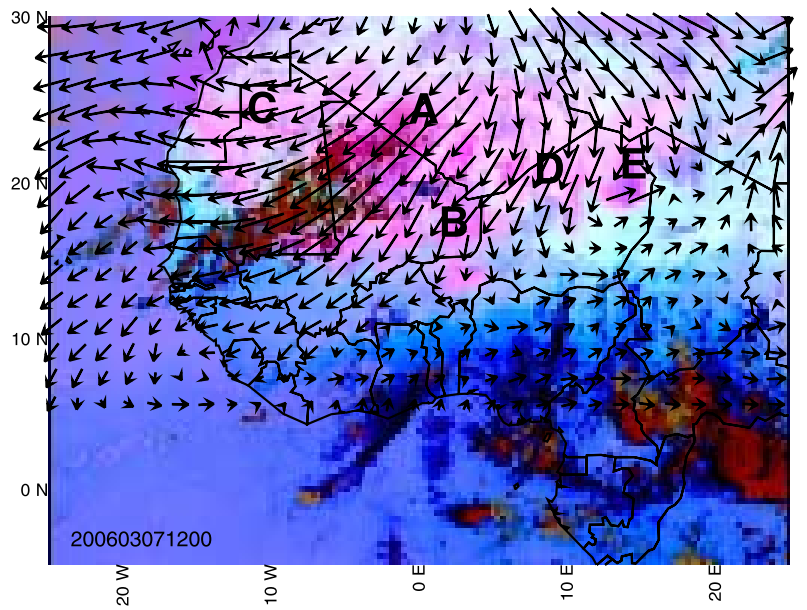

d)

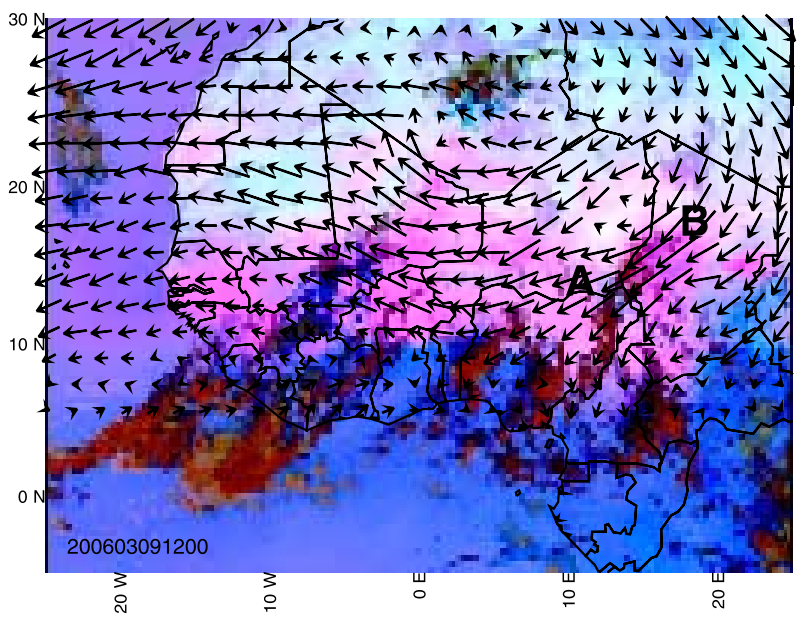

Figure 8. SEVIRI false color dust product imagery at 1200 UTC each day over the study period. Pink tones indicate dust. RegCM3 EXP1 925-hPa wind vectors are overlaid. Letters are explained in the text.

[20] Simulated AOT from experiments EXP1 and EXP2 are shown in Figures 9 and 10, respectively. It is of interest to determine the extent to which the model simulates these localized dust sources accurately. Overall, both model experiments represent well the dominant features of the event. Specifically, (1) the pronounced dust emission over much of the Sahara, (2) the northwest to southeast evolution of dust source activation over the period, from northern Algeria on 6 March to parts of Niger and eastern Chad on 7 and 8 March, and (3) the transport of dust to the south and southwest over the Atlantic/Sahel sector by 9 March. However, it is clear that EXP2 provides a much more realistic representation of the key localized source regions evident in the SEVIRI imagery (Figure 8). Most notably, in EXP2 dust emission from the southern flanks of the Hoggar mountains on 7 March (feature A in Figure 8a), the Tchigai plateau on 7-8 March (features $\mathrm{E}$ in Figure $8 \mathrm{~b}$ and $\mathrm{C}$ in Figure 8c) and the regions to the north and south of the Air mountains on 8-9 March (feature A in Figures 8c and 8d) match very closely with SEVIRI. In EXP1 dust emission from these regions is $\mathrm{y}$ absent. Emission from the
Bodélé depression is more realistically extensive in EXP2. Both experiments show an extensive area of emission over central Mauritania on 7 March which is probably overestimated relative to SEVIRI. There is some indication from SEVIRI that dust is transported farther south (to $\sim 10^{\circ} \mathrm{N}$ ) from 8 March onward, than is represented in the model. For example the dust plume covers Burkina Faso in SEVIRI but in the model the plume is located north of $13.5^{\circ} \mathrm{N}$ owing to the influence of easterly winds which prevent propagation of the plume farther south. It is likely that the model has an error in the circulation here. Overall, EXP2 has a higher mean AOT by about a factor of 2 when compared against EXP1.

[21] The OMI-AOT and limited MISR AOT observations (Figure 11) serve to confirm all the key dust plume features identified from SEVIRI mentioned above. It is evident that in a qualitative sense EXP2 represents these features more comprehensively than does EXP1, illustrated by a stronger spatial correspondence between model AOT and satellite AOT (Figures 11 and 12). However, in EXP2 AOT is clearly overestimated relative to MISR by about a factor 

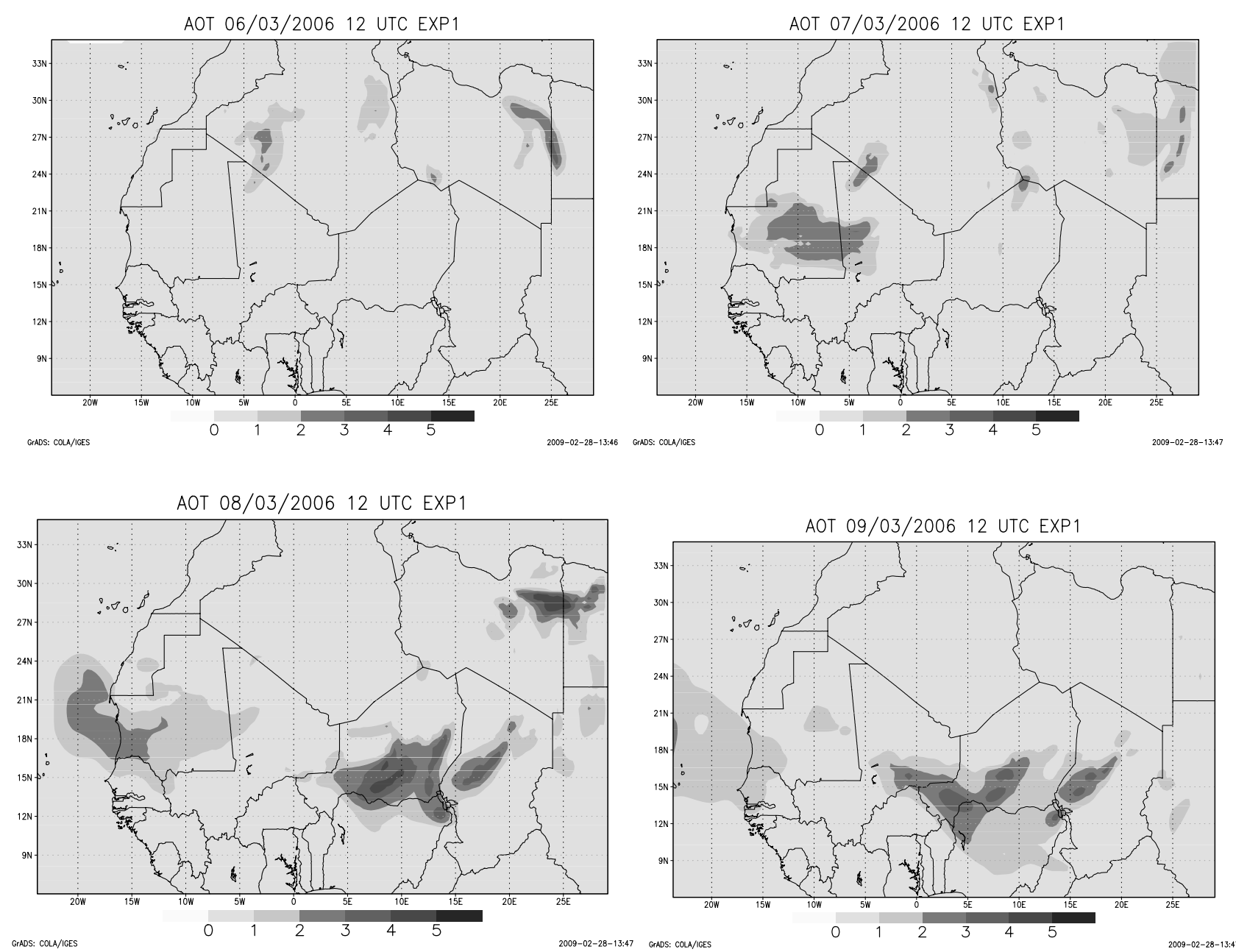

Figure 9. Model simulated AOT at 1200 UTC each day over the study period from EXP1.

of 2 (Figure 11). The model overestimation relative to OMI-AOT is even higher (Figures 11 and 12). However, it should be noted that there is a considerable underestimation of AOT by OMI compared to MISR (Figure 12a), suggesting that the relationship used to derive the former from the latter [Christopher et al., 2008] is not especially robust for this case study period. It should be noted also that MISR underestimates AOT relative to the AERONET observations by a factor of $\sim 2$ and that model AOT is broadly in line with that estimates from AERONET (see below).

[22] Quantitative evaluation of model AOT using AERONET Sun photometer data is largely limited to the locations in the Sahelian sector (Figure 1) such that the observations tend to reflect long-range dust transport from the Sahara rather than local dust emission. The only Saharan site at Tamanrasset is at a relatively high elevation in a region of complex topography and so it is not strongly influenced by local dust emission (AOT values observed did not exceed $0.2)$ therefore it was not considered in this study. The correspondence between modeled and observed AOT (Figure 13) is variable between stations, indicating that some transport pathways are well simulated and others not. Overall, there is no clear evidence of systematic model overestimation of AOT, while MISR and especially OMI-AOT underestimate relative to AERONET. is a particularly close corre- spondence between observed and modeled AOT at the sites Maine Soroa $\left(12.02^{\circ} \mathrm{E}, 13.21^{\circ} \mathrm{N}\right)$, in southeast Niger, Dakar $\left(16.95^{\circ} \mathrm{W}, 14.39^{\circ} \mathrm{N}\right)$ on the Atlantic coast of Senegal and Capo Verde $\left(22^{\circ} \mathrm{W}, 14.39^{\circ} \mathrm{N}\right)$. Maine Soroa lies directly downwind of the both the Ténéré desert in northern Niger (including the Tchigie Plateau) which was active on $7-$ 8 March and the Bodélé depression to the northeast, active 8-9 March. Dust transport to Maine Soroa takes in excess of $12 \mathrm{~h}$ from both source regions. As such, the time series of observed AOT show elevated values on 8-10 March with peak values (AOT $>4.0)$ on 9 March. SEVIRI imagery indicates that the major dust plumes pass Maine Soroa primarily at night so that the observed AERONET AOT values do not indicate the magnitude of the dust peak. The time evolution of AOT is well simulated in both EXP1 and EXP2, with EXP1 resolving the magnitude better on 8 and 10 March, whereas EXP2 captures the peak values on 9 March. A previous study of the Bodélé Depression region [Todd et al., 2008a] indicated that the default RegCM3 configuration rather underestimated dust emission from this region, such that we might expect the dust emission in EXP2 to be rather more realistic than in EXP1. At Dakar, the time evolution of dust transport is well captured by the models with dust emitted from Mauritania-Mali region reaching the site on 8 March, peaking on 9 March and declining thereafter. EXP2 

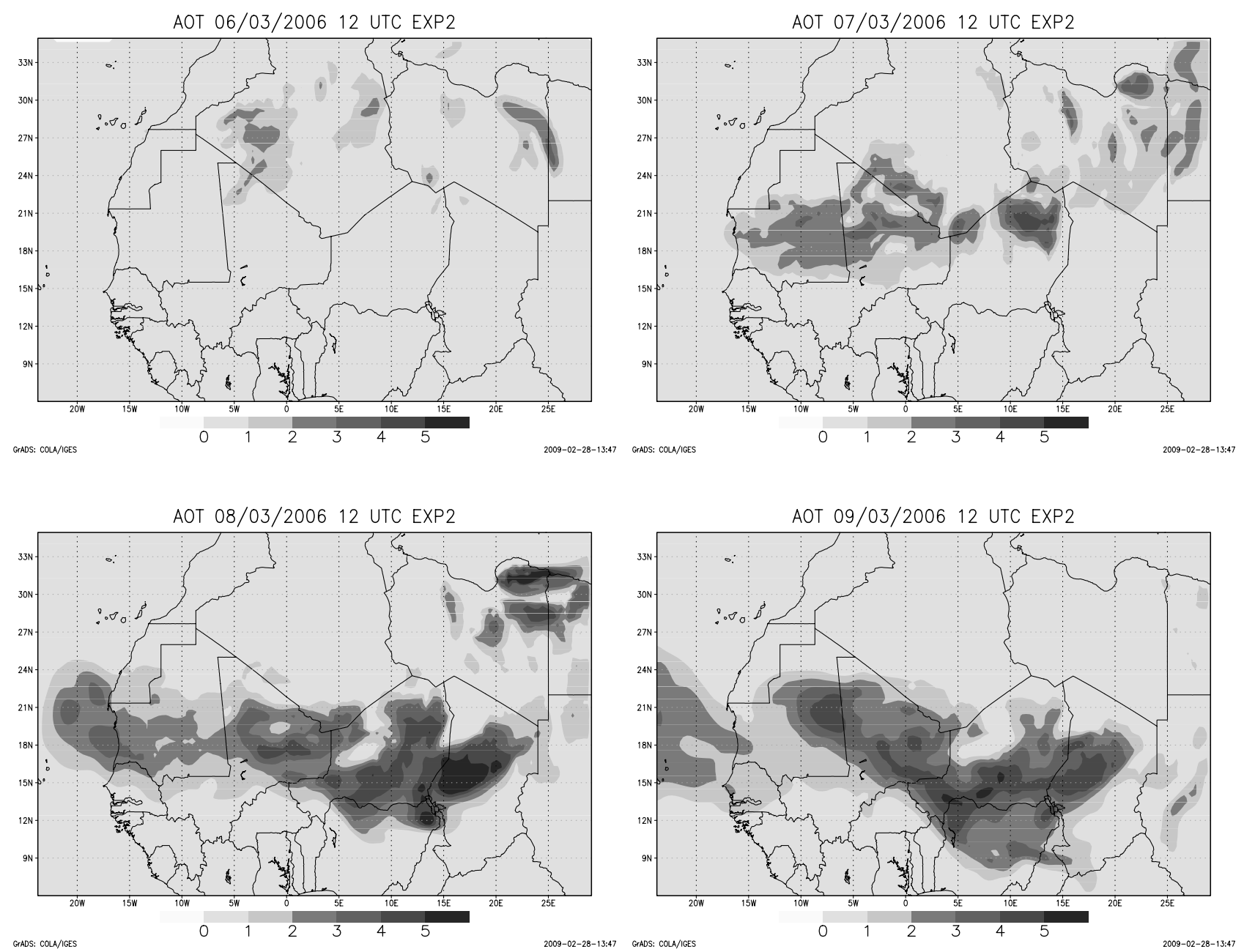

Figure 10. Model simulated AOT at 1200 UTC each day over the study period from EXP2.

estimates the magnitude of AOT far better than EXP1. Farther west at Capo Verde the AERONET station shows elevated AOT on 8 March, peaking on 9 March, a pattern very closely represented by the model, especially EXP2. Although dust advection over the eastern Atlantic is well represented at these sites, farther north the model underestimates the magnitude of AOT at Tenerife, although the time evolution is reasonably accurate.

[23] For the Sahelian sites, the closest correspondence occurs at the northernmost station of Agoufou $\left(1.5^{\circ} \mathrm{W}\right.$, $15.3^{\circ} \mathrm{N}$ ) where enhanced atmospheric turbidity begins on 7 March, peaks on 9 March before declining to background levels on 12 March. The models capture this pattern well, especially for the EXP2 in which the maximum peak observed of AOT ( $>4)$ on 9 March coincides with that of the site. At other Sahelian sites, however, the observed AOT is less well represented. At Banizoumbou $\left(2.66^{\circ} \mathrm{E}, 13.54^{\circ} \mathrm{N}\right)$ and Djougou $\left(1.54^{\circ} \mathrm{E}, 9.76^{\circ} \mathrm{N}\right)$ elevated AOT evident on 7 and 8 March is not apparent in the model which shows dust only from 9 March onward. Analysis of the SEVIRI imagery shows that this model error is due to dust emission in southern Niger, north of Banizoumbou on 7 March and the subsequent southward advection. This particular dust source is not resolved in EXP2, indicating an omission in the dust plume identifi by Schepanski et al. [2007].
The AERONET stations located farther south at Ilorin $\left(4.3^{\circ} \mathrm{E}, 8.3^{\circ} \mathrm{N}\right)$ and Djougou $\left(1.5^{\circ} \mathrm{E}, 9.76^{\circ} \mathrm{N}\right)$ identify the southward transport of dust toward the Gulf of Guinea reaching Ilorin on 10 March, peaking on 11 March and then slowly declining with elevated AOT values $(>1.0)$ persisting until 16 March. The model generally underestimates the magnitude of AOT in this southern zone indicating either excessive dust deposition rates, errors in the southward circulation or the influence of nondust aerosols (i.e., biomass burning) in the AERONET observations. However, we can assume that the observed AOT values are largely caused by desert dust rather than biomass burning and urban/industrial aerosol as the Angstrom coefficients $(\alpha)$ are below 1.0, indicative of large dust particles [Dubovik et al., 2002]. Model error in the circulation is suggested also by comparison of model AOT and satellite imagery (Figures $8-11$ ). It is interesting to note that the limited comparison available between the satellite products and surface-based AERONET AOT indicates that MISR and OMI-AOT substantially underestimate the elevated AOT values during the dust event at almost all the AERONET sites. As such, the apparent overestimation of model AOT relative to MISROMI (Figures 9-11) may partly reflect this. Overall, it is reasonable to conclude that EXP2 better resolves dust source regions than EXP1 and provides a more represen- 

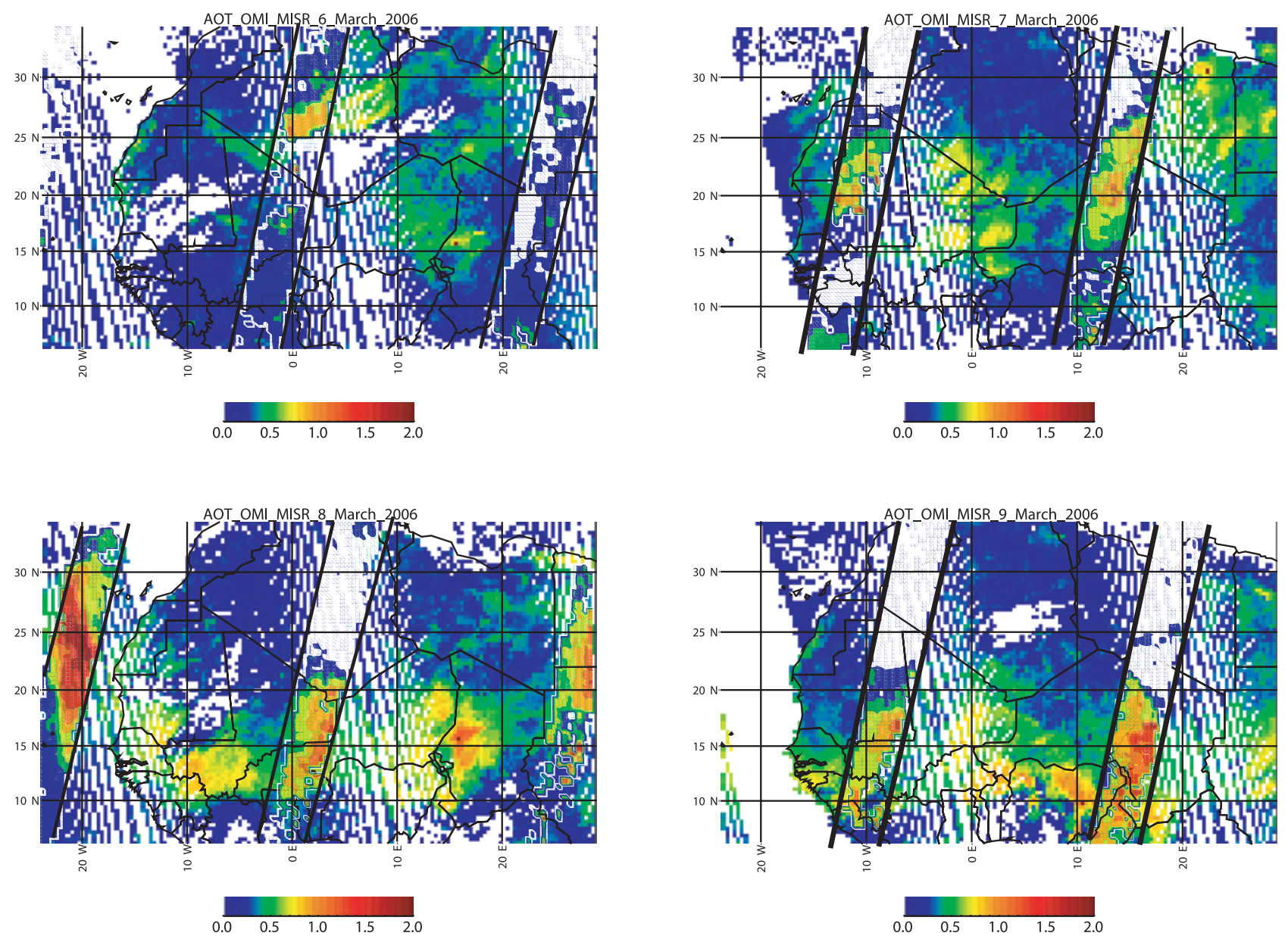

Figure 11. Estimated AOT for OMI at 1330 local time each day over the study period, 6-9 March 2006. MISR AOT at 1045 local time is overplotted.

tative estimate of the space/time distribution of dust and AOT.

[24] It is well known that Saharan dust is advected by the planetary-scale circulation and transported many thousands of kilometers around the globe [Swap et al., 1992]. The impact of this on climate and remote ecosystems will depend on the mass flux along with the optical and physical properties of the dust from the emitting region [Liao and Seinfeld, 1998]. Previous attempts have been made to quantify the mass flux from observations [Kaufman et al., 2005b; Koren et al., 2006]. Here, we derive the mass flux of dust from the region estimated by RegCM3 from the product of the meridional and zonal wind speed and dust concentration in each model layer, summed over the atmospheric column. Dust transport is dominated by a southwestward flux in the Harmattan northeasterly flow such that in the vertical integration calculation at levels where the zonal wind component is eastward or the meridional component is northward the dust flux is considered to be negative. The net westward zonal and southward meridional components are derived. The net flux of dust exported southward from the Sahara to the West African land regions, determined from the meridional component at $15^{\circ} \mathrm{N}$ averaged over longitudes $15^{\circ} \mathrm{W}-25^{\circ} \mathrm{E}$ and is 1.67 (2.5) $\mathrm{Tg} \mathrm{d}^{-1}$, for EXP1 (EXP2), which may have implications for the Sahelian and equatorial an ecosystems. The westward net flux leaving the west coast of Africa over the Atlantic Ocean is determined from the zonal component at $15^{\circ} \mathrm{W}$ over the latitude range $0^{\circ}-30^{\circ} \mathrm{N}$. For the 5 -day period $6-$ 11 March the flux is 1.05 (1.65) $\mathrm{Tg} \mathrm{d}^{-1}$ for EXP1 (EXP2). Kaufman et al. [2005b] use a similar method to estimate the mass flux of dust from North Africa on the basis of the product of mean monthly MODIS satellite estimated AOT and NCEP reanalysis $850-\mathrm{hPa}$ winds. Using their method applied to RegCM3 model 850-hPa wind speed and AOT the flux for 6-11 March 2006 is 1.8 (2.7) $\mathrm{Tg} \mathrm{d}^{-1}$ for EXP1 (EXP2), which is about 1.5 times higher than that derived using the full vertical distribution of winds and dust mass. Kaufman et al. [2005b] estimate the dust flux leaving West Africa at $15^{\circ} \mathrm{W}$ over the latitude range $0^{\circ}-30^{\circ} \mathrm{N}$ during winter months of 2001 to be about $0.3 \mathrm{Tg} \mathrm{d}^{-1}$. Our estimates of mass flux during the March 2006 event highlight the importance of these major events to total mass flux.

\subsection{Model Simulation of Dust Radiative Impact}

[25] At present, the RegCM3 model only determines the aerosol impact on shortwave (SW) radiative fluxes. The SW radiative forcing $\left(\mathrm{RF}_{\mathrm{SW}}\right)$ is determined at the surface (SFC) and top of the atmosphere (TOA) (Figures 14 and 16). Associated temperature anomalies are determined from the difference between the results of EXP1 and EXP2 and the control run ND without active dust (Figure 15). At the height 
a)

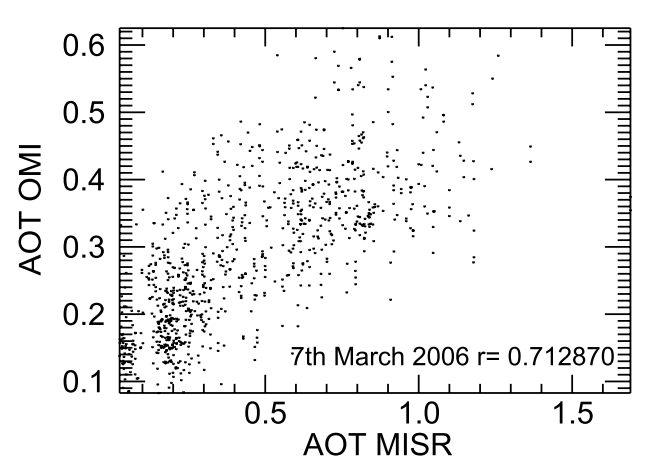

b)

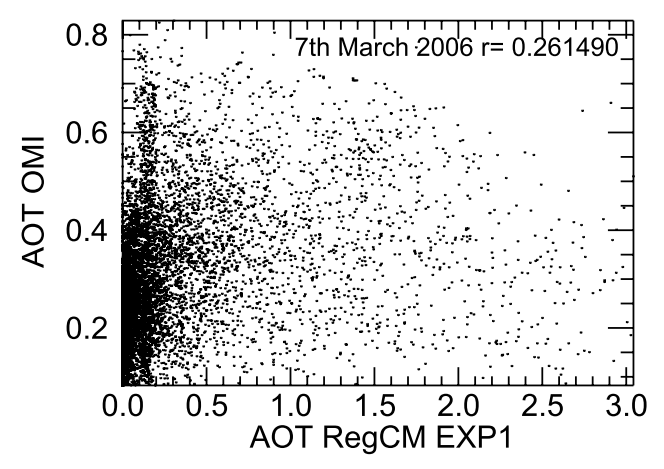

c)

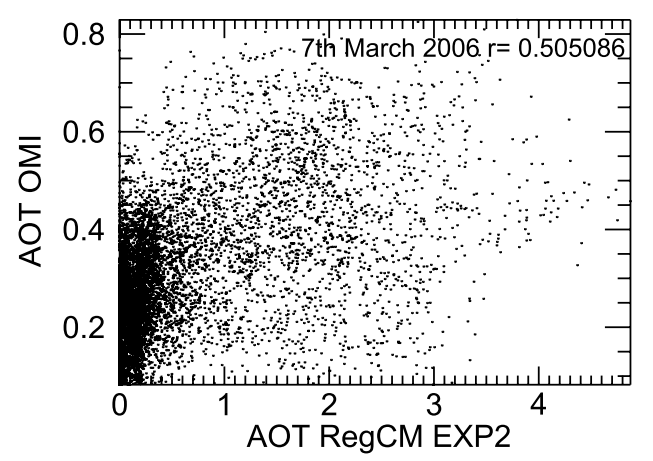

Figure 12. Example AOT scatterplot for 1200 UTC on 7 March over model domain. (a) MISR AOT versus OMIAOT, (b) AOT EXP1 versus AOT estimated OMI-AOT, and (c) AOT EXP2 versus OMI-AOT.

of the dust event at 12UTC on 8 March $\mathrm{RF}_{\mathrm{SW}(\mathrm{SFC})}$ peaks at around $-550 \mathrm{~W} \mathrm{~m}^{-2}\left(-650 \mathrm{~W} \mathrm{~m}^{-2}\right)$ downwind of the major dust source over the Bodélé Depression for EXP1 (EXP2) (Figure 14). The peak domain averaged $\mathrm{RF}_{\mathrm{SW}(\mathrm{SFC})}$ is $-71 \mathrm{~W} \mathrm{~m}^{-2},-128 \mathrm{~W} \mathrm{~m}^{-2}$ and $-123 \mathrm{~W} \mathrm{~m}^{-2}$ for EXP1, EXP2 and EXP2b ( $\omega_{\mathrm{o}}$ values increased), respectively, indicating how the $\mathrm{RF}_{\mathrm{SW}(\mathrm{SFC})}$ is far more sensitive to the areal dust emission than the range of optical properties in these experiments. The domain averaged $\mathrm{RF}_{\mathrm{SW}(\mathrm{SFC})}$ normalized by AOT is comparable for the three experiments $\left(-139 \mathrm{~W} \mathrm{~m}^{-2}\right.$, $-151 \mathrm{~W} \mathrm{~m}^{-2}$ and $-132 \mathrm{~W} \mathrm{~m}^{-2}$ per unit AOT, for EXP1, EXP2 and EXP2b, respectively). These are close to that estimated during the $\mathrm{S}$ experiment over the Atlantic off the coast of west Africa $\left(-129 \mathrm{~W} \mathrm{~m}^{-2}\right)$ [Haywood et al., 2003]. Compared to field observations at single sites at Niamey, southern Niger these results are very close to the $-130 \mathrm{~W} \mathrm{~m}^{-2}$ obtained by Fouquart et al. [1987] but higher than the observed impact of $\sim 100 \mathrm{~W} \mathrm{~m}^{-2}$ per unit AOT reported by Slingo et al. [2006]. Our results are somewhat lower than those obtained in a similar model study by Helmert et al. [2007] over the southern Sahara for aerosols with varying optical properties $\left(-220\right.$ to $-196 \mathrm{~W} \mathrm{~m}^{-2}$ per unit AOT).

[26] The magnitude of reductions in daytime maximum air temperature between the day prior to and during the dust event agree well with station observations (Figure 3 ) and are often in excess of $10^{\circ} \mathrm{C}$. These temperature anomalies result from a combination of horizontal and vertical temperature advection and diabatic heating (consisting of radiant fluxes and surface heat fluxes, which are dominated by sensible heat flux). Given the strength of the northerly wind anomalies (Figures $3 \mathrm{~b}$ and 8 ) and the $\mathrm{RF}_{\mathrm{SW}(\mathrm{SFC})}$ it is likely that both advective and diabatic heating contributions are substantial. We can estimate the magnitude of each of these components by comparing the temperature simulated by RegCM3 experiments with active dust to the control run (ND), for grid cells where cloud differences are minimal. The effect of the $\mathrm{RF}_{\mathrm{SW}(\mathrm{SFC})}$ is to reduce daytime surface temperatures, by more than $8^{\circ} \mathrm{C}\left(10^{\circ} \mathrm{C}\right)$ in EXP1 (EXP2) where aerosol loadings are highest (Figure 15). Temperature anomalies directly attributable to $\mathrm{RF}_{\mathrm{SW}(\mathrm{SFC})}$ exceed $5^{\circ} \mathrm{C}$ across much of the dust plume region. The daytime maximum temperature anomaly normalized by AOT averaged over the domain for grid cells where AOT $>0.5$ is about $2.5^{\circ} \mathrm{C}$ per unit AOT in both EXP1 and EXP2, slightly higher than the value of $2.1-2.2^{\circ} \mathrm{C}$ per unit AOT derived by Helmert et al. [2007].

[27] The $\mathrm{RF}_{\mathrm{SW}}$ at the top of atmosphere associated with aerosols is a function of the aerosols loading, optical properties, size distribution, and surface albedo. $\mathrm{RF}_{\mathrm{SW} \text { (TOA) }}$ is strongly negative over areas where the aerosol load is high and surface albedo is low (Figure 16). This is most notable over the Atlantic Ocean off the coast of Mauritania and over northern Nigeria and southern Niger where the instantaneous $\mathrm{RF}_{\mathrm{SW} \text { (TOA) }}$ has a minimum of about $-180 \mathrm{~W}$ $\mathrm{m}^{-2}$. Over the Sahara itself $\mathrm{RF}_{\mathrm{SW}(\mathrm{TOA})}$ is positive, with instantaneous peak values in excess of $+60 \mathrm{~W} \mathrm{~m}^{-2}$ over parts of Niger and Chad in particular, as the dust aerosols produce an effective decrease in the planetary albedo over the bright desert surfaces (Figure 16). The effect of the higher aerosol $\omega$ o in EXP2b results in a lower $\mathrm{RF}_{\mathrm{SW}(\mathrm{TOA}) \text {, }}$ i.e., more negative over dark surface and less positive over bright surfaces (Figure 16). Nevertheless, the fundamental distinction in the sign of the $\mathrm{RF}_{\mathrm{SW} \text { (TOA) }}$ between dark and bright surfaces (along $15^{\circ} \mathrm{N}$ over land) remains in EXP2b. The aggregate effect of this complex spatial structure in $\mathrm{RF}_{\mathrm{SW} \text { (TOA) }}$ simulated by RegCM3 is negative when averaged over the domain, and the magnitude increases over the study period to peak at $-16,-27$, and $-33 \mathrm{~W} \mathrm{~m}^{-2}$ for EXP1, EXP2 and EXP2b, respectively, at 1500 UTC on 9 March as the dust plume shifts from the desert regions to darker surfaces in the south of the domain (not shown). The space/time averaged $\mathrm{RF}_{\mathrm{SW}(\mathrm{TOA})}$ is $-4.7,-7.6,-9.15 \mathrm{~W} \mathrm{~m}^{-2}$ for EXP1, EXP2 and EXP2b, respectively. The space/time average normalized $\mathrm{RF}_{\mathrm{SW}(\mathrm{TOA})}$ is $\sim-10 \mathrm{~W} \mathrm{~m}^{-2}$ per unit 
Santa Cruz Tenerife $\left(16.2^{\circ} \mathrm{W}, 28.4^{\circ} \mathrm{N}\right)$

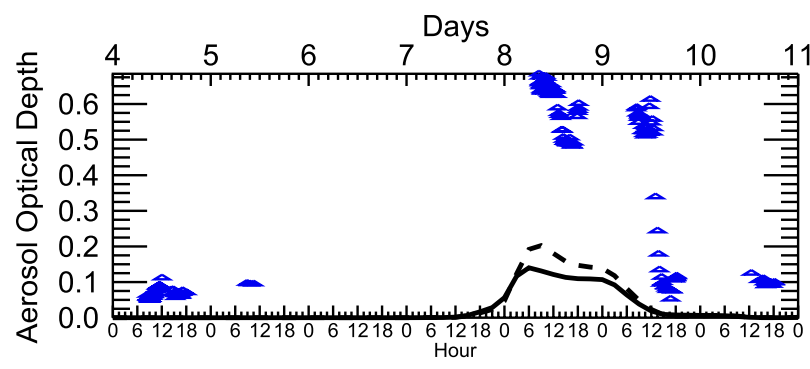

DMN Maine Soroa $\left(12^{\circ} \mathrm{E}, 13.2^{\circ} \mathrm{N}\right)$

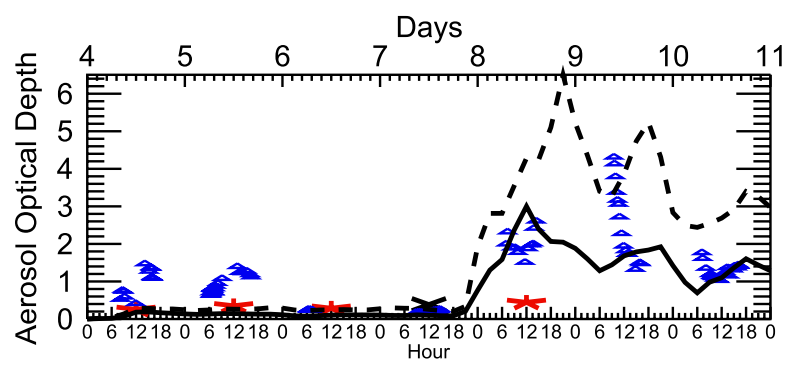

Banizoumbou $\left(\mathrm{C} 2.66^{\circ} \mathrm{E}, 13.54^{\circ} \mathrm{N}\right)$

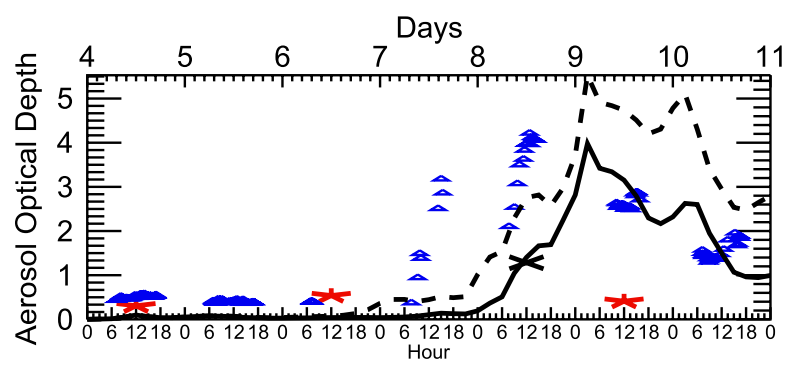

Agoufou $\left(1.0^{\circ} \mathrm{W}, 15^{\circ} \mathrm{N}\right)$

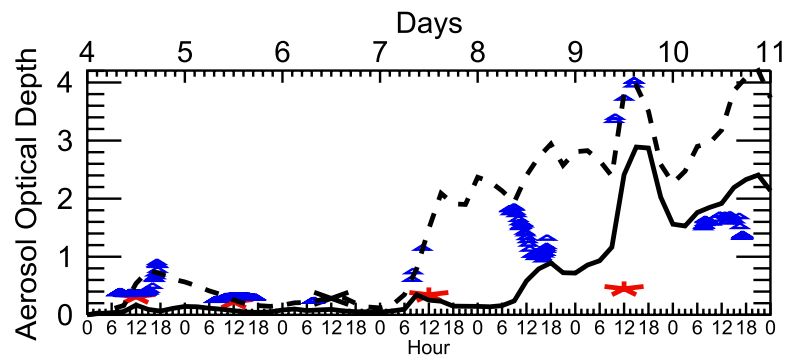

Dakar $\left(16.95^{\circ} \mathrm{W}, 14.39^{\circ} \mathrm{N}\right)$

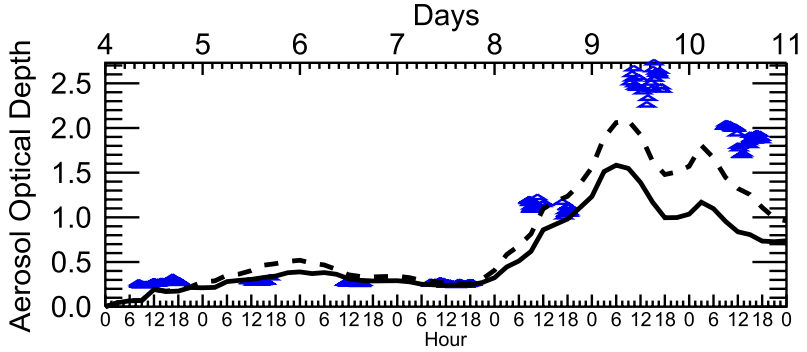

Ilorin $\left(4.34^{\circ} \mathrm{E}, 8.32^{\circ} \mathrm{N}\right)$

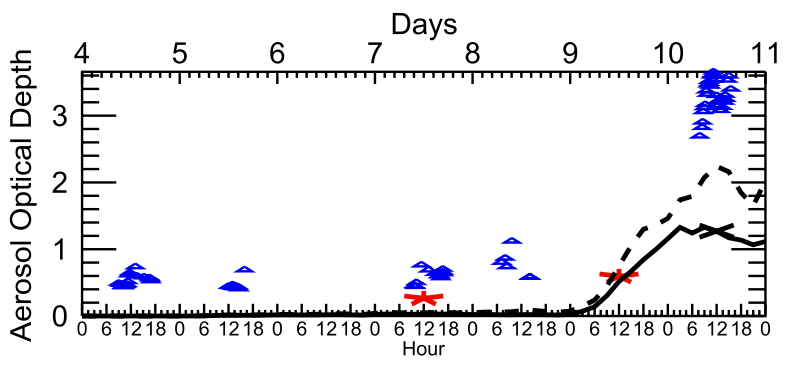

Djougou $\left(1.54^{\circ} \mathrm{E}, 9.76^{\circ} \mathrm{N}\right)$

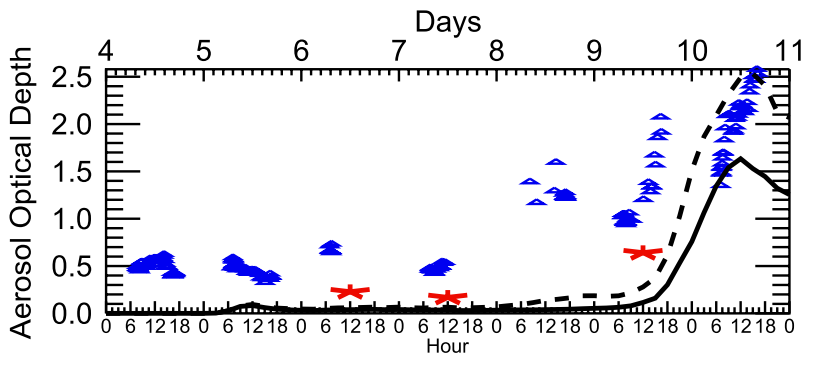

Capo Verde $\left(22^{\circ} \mathrm{W}, 16^{\circ} \mathrm{N}\right)$

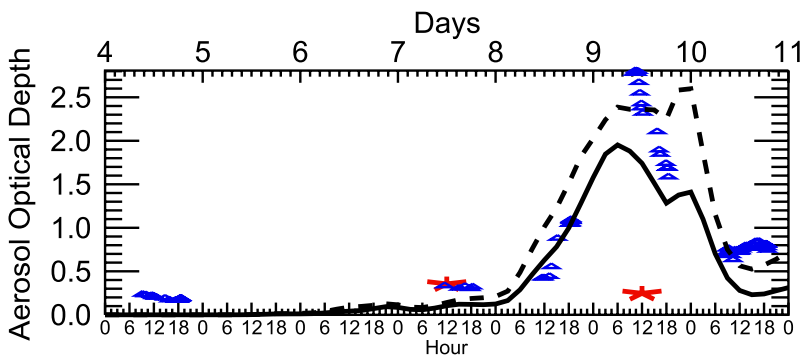

Figure 13. Time series of observed and model simulated AOT at the locations of the AERONET Sun photometer stations: $440 \mathrm{~nm}$ AOT from AERONET (triangles), AOT from EXP1 (dotted curves), AOT from EXP2 (dashed curves), coincident MISR-AOT (crosses), and OMI-AOT (asterisks) observations.

AOT in both EXP1 and EXP2 whereas this value increases to $-12 \mathrm{~W} \mathrm{~m}^{-2}$ for EXP2b. Clearly these averaged figures are particular to the domain specified here. Over the darker land surfaces of the Sahelian zone model simulated instantaneous peak $\mathrm{RF}_{\mathrm{SW}}$ (TOA) normalized by $\mathrm{AOT}$ are $\sim-80$ to $-40 \mathrm{~W} \mathrm{~m} \mathrm{~m}^{-2}$ per unit AOT for both EXP1 and EXP2, respectively (not shown). At the location of Niamey, Niger the value is $-40 \mathrm{~W} \mathrm{~m} \mathrm{~m}^{-2}$, roughly consistent with the observations from the GERB (Geostationary Earth Radiation Budget experiment and CERES (Clouds and the
Earth's Radiant Energy System) instruments [Slingo et al., 2006].

[28] This spatial structure in $\mathrm{RF}_{\mathrm{SW}(\mathrm{TOA})}$ simulated by RegCM3 with positive forcing over desert regions and negative forcing over dark surfaces is consistent with model simulations by Perez et al. [2006] but contrasts with those of Helmert et al. [2007] and Myhre et al. [2003], who document a consistently negative $\mathrm{RF}_{\mathrm{SW}}$ (TOA) even over bright surfaces. Even with the aerosol $\omega_{\mathrm{o}}$ modified to represent the more highly reflective aerosols the $\mathrm{RF}_{\mathrm{SW}}(\mathrm{TOA})$ remains positive 
a)

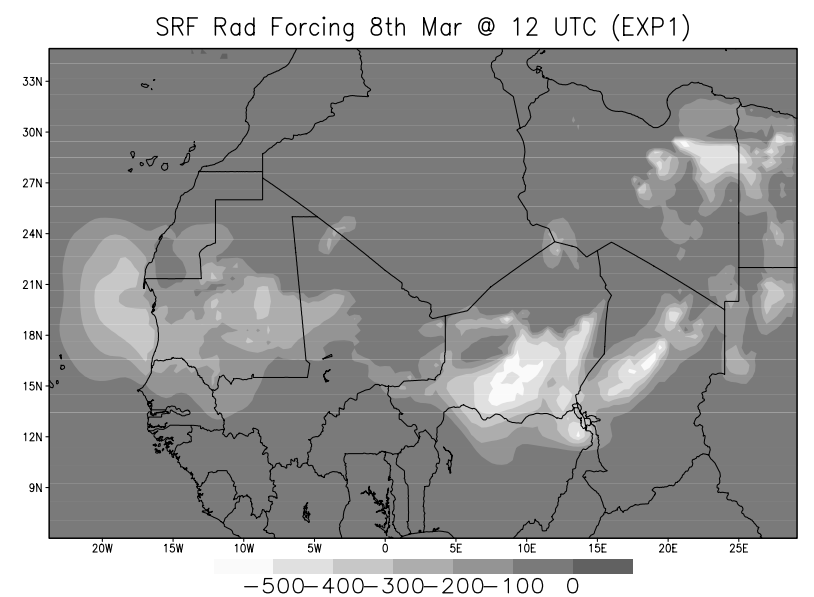

GrADS: COLA/IGES

c)

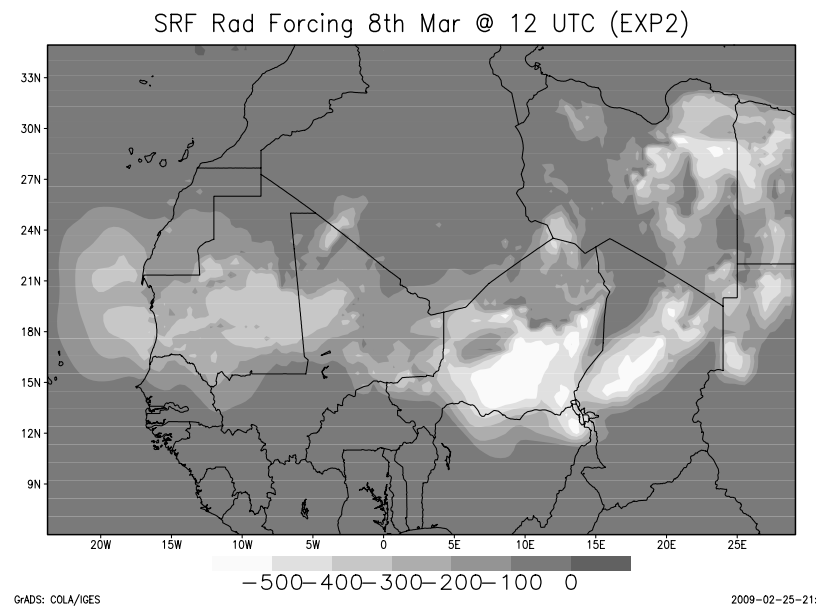

e)

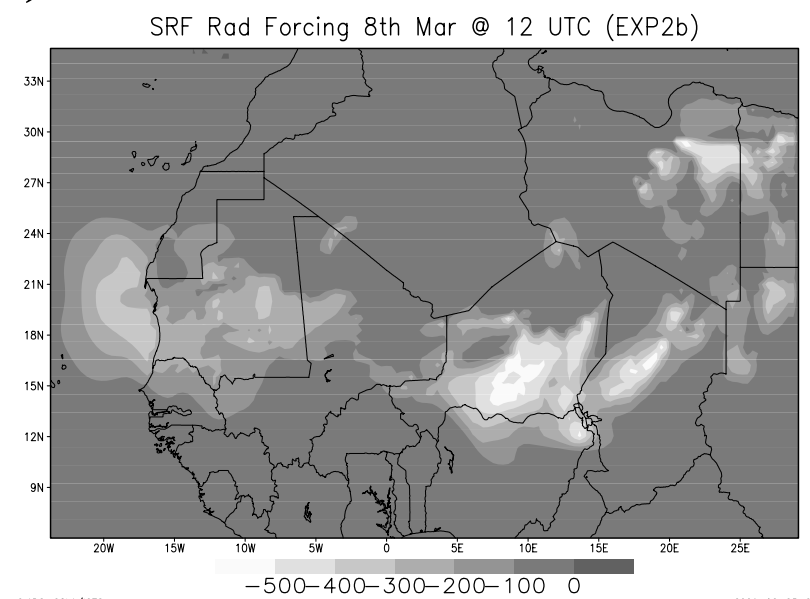

b)

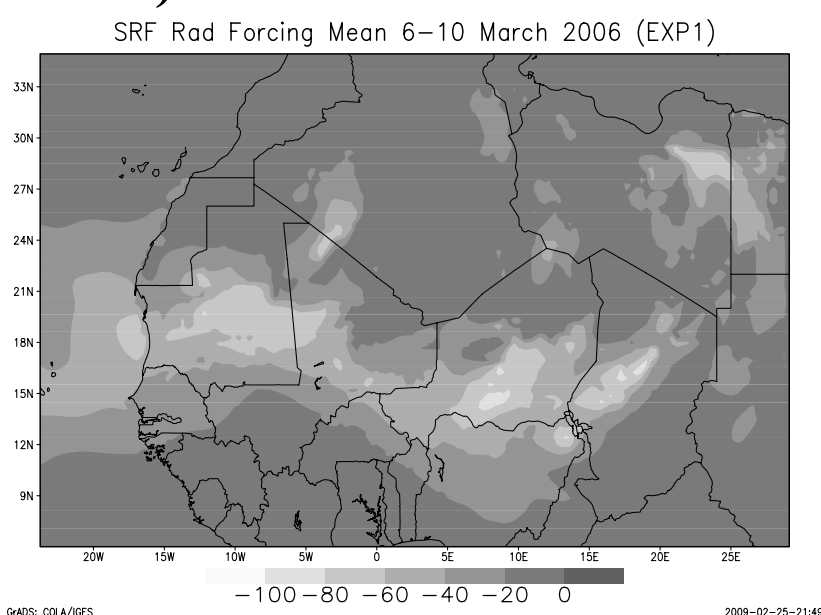

d)

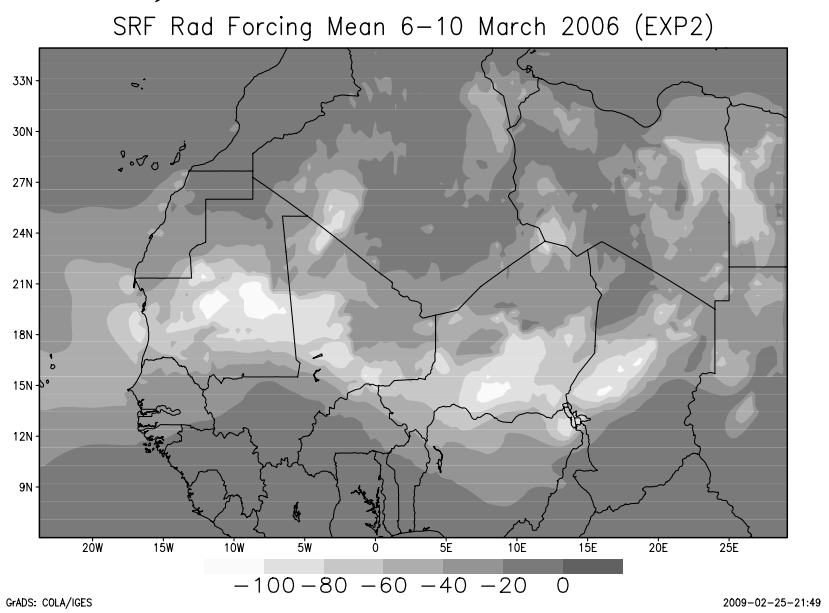

f)

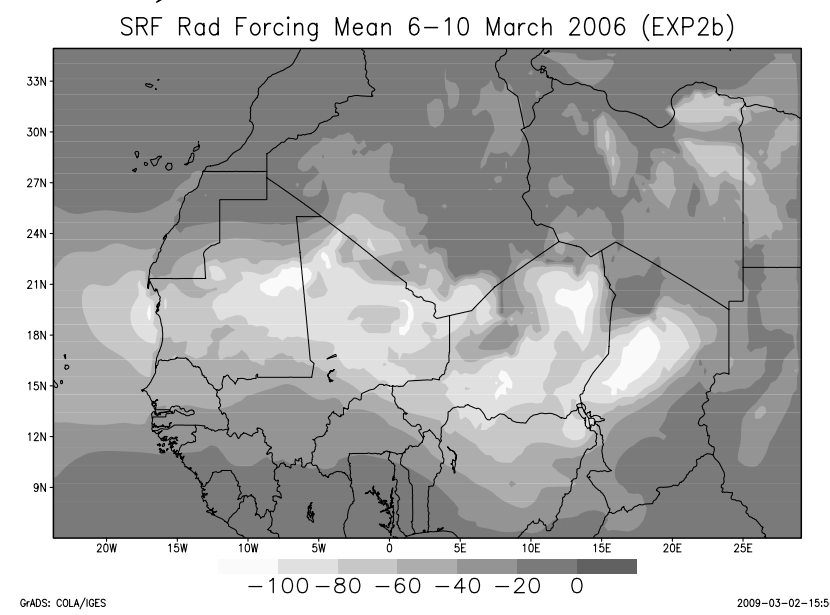

Figure 14. Shortwave radiative forcing at the surface $\left(\mathrm{W} \mathrm{m}^{-2}\right)$. (a) Mean (6-10 March 2006) EXP1, (b) instantaneous 1200 UTC March 8 EXP1, (c) as in Figure 14a but for EXP2, (d) as Figure 14b but for EXP2, (e) as in Figure 14a but for EXP2b, and (f) as in Figure 14b but for EXP2b.

over bright surfaces (EXP2b). As such it is likely that the disparity between EXP2b and the simulations of Helmert et $a l$. [2007] is likely to result from differences in surface albedo over the desert regions. gCM3 the albedo is typically around 0.33 over desert (Figure 17) similar to those observed from the ERBE (Earth Radiation Budget Experiment) satellite sensor obtained from the NASA Langley Research Center Atmospheric Science Data Center (not shown), in 


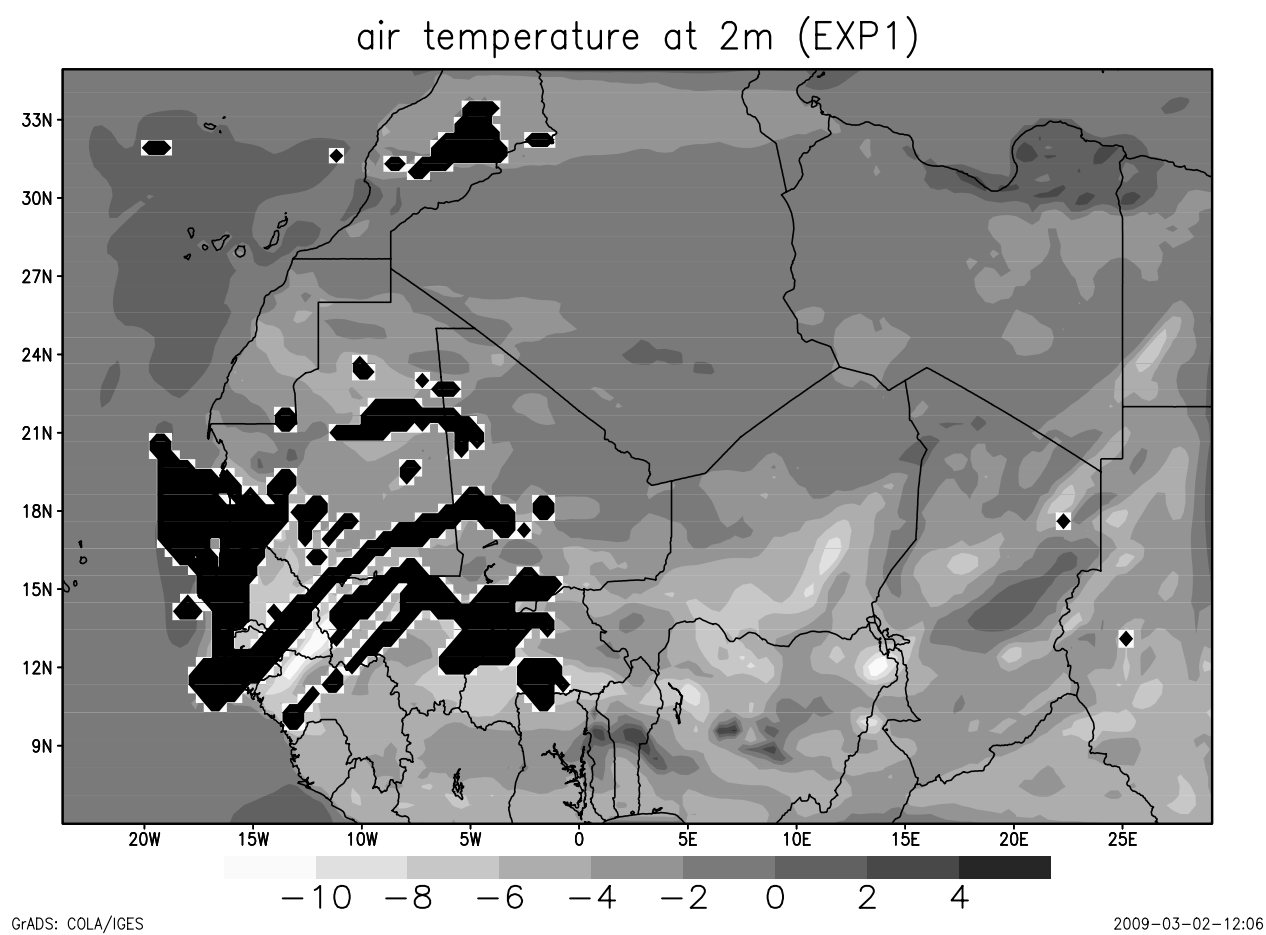

air temperature at $2 m(E X P 2)$

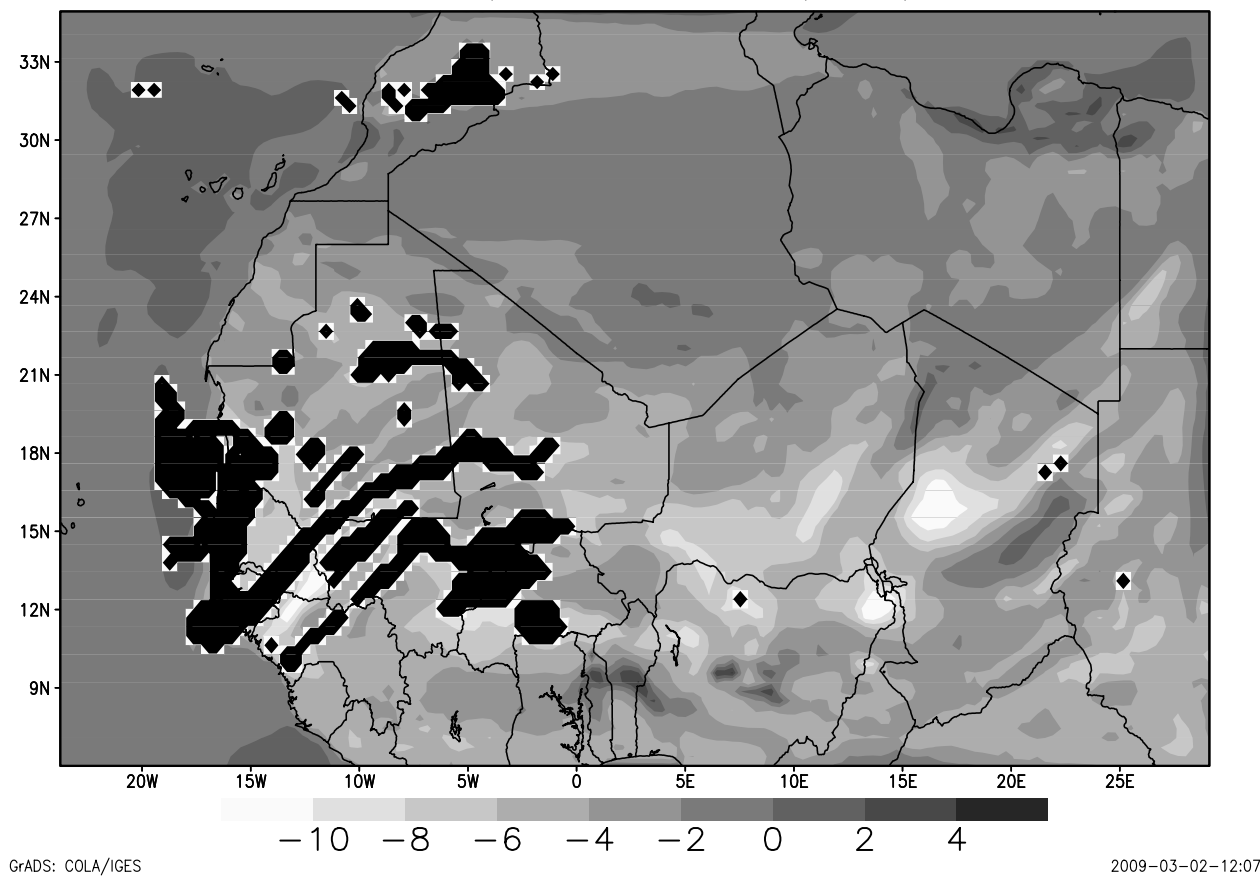

Figure 15. The 2-m temperature anomalies $\left({ }^{\circ} \mathrm{C}\right)$ for 1200 UTC 8 March: (top) EXP1-ND and (bottom) EXP2-ND. A black mask is created when cloud fraction is greater than $20 \%$.

contrast to values of $\sim 0.2$ from Helmert et al. [2007]. As such, the results of these modeling experiments illustrate how important it is to specify accurately not only the optical properties of aerosols but also the surface albedo.

\section{Conclusion}

[29] This study has evaluated the ability of the RegCM3 regional climate model ctive dust module to simulate the large Saharan dust event of 6-11 March 2006. This event was undoubtedly one of the most dramatic dust events ever recorded, with multiple source regions across the entire Sahara desert activated. The resulting dust plume extended for thousands of kilometers across the Atlantic and west African sector. Dust activation was associated with strong winds at the leading edge of an explosive cold surge. The dust/wind front propagated south and southeast form northern Algeria over a period of about 3 days. The RegCM3 model 
a)

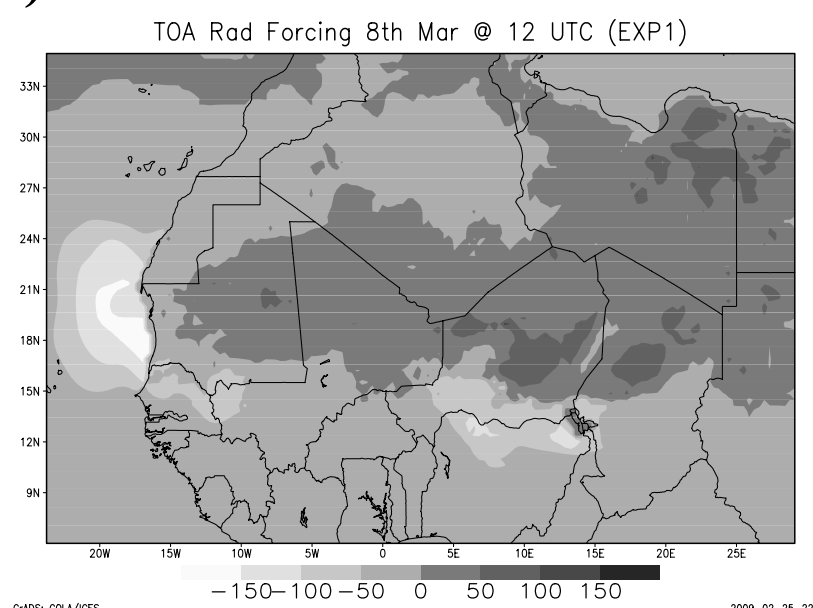

c)

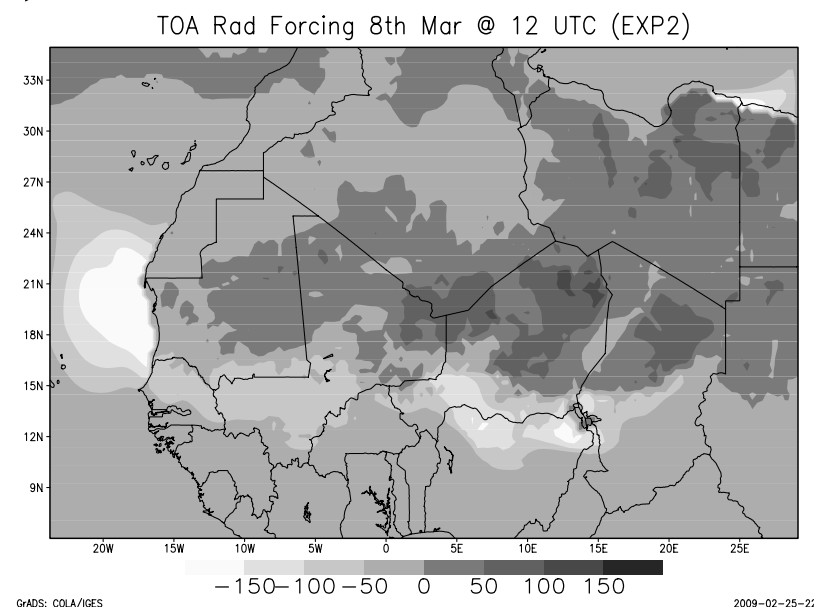

e)

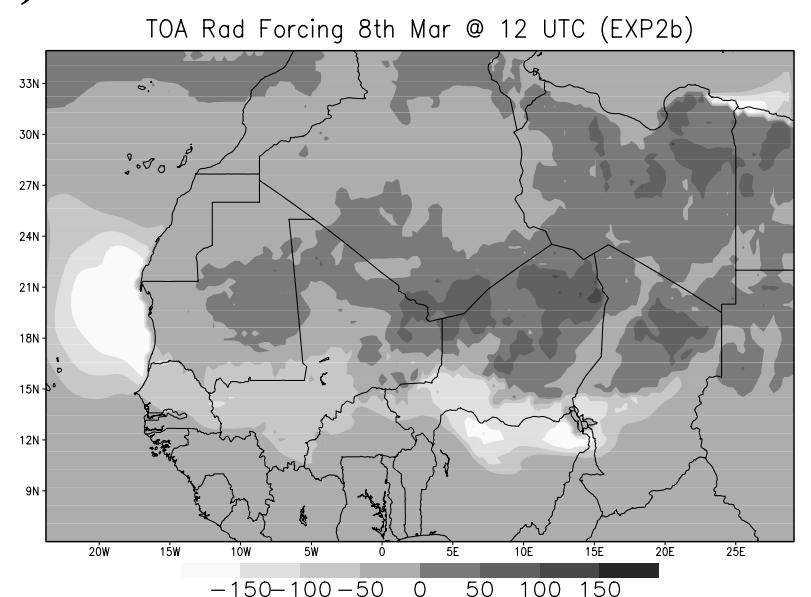

b)

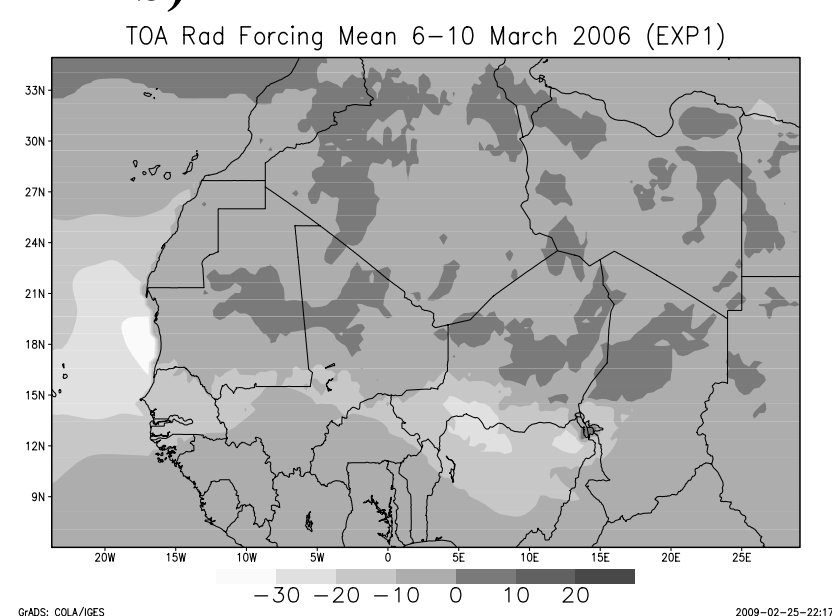

d)

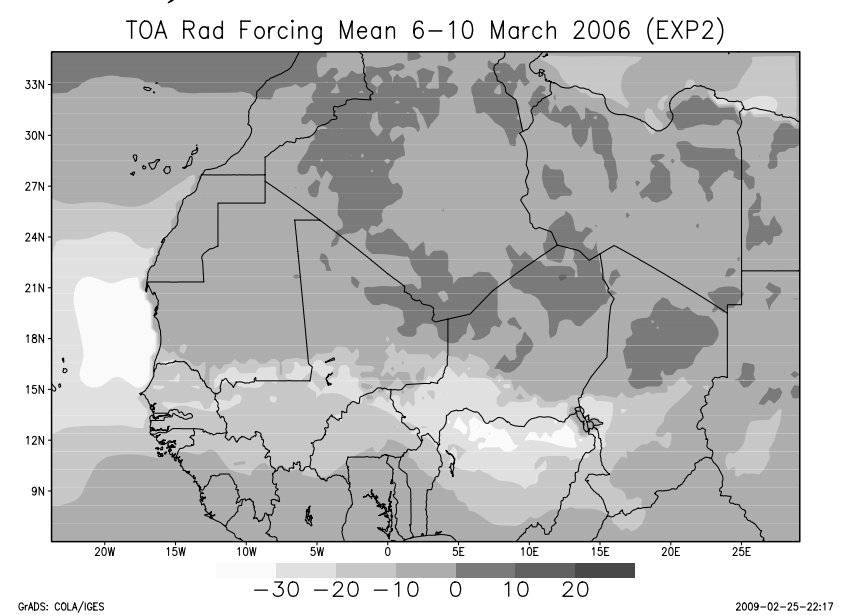

f)

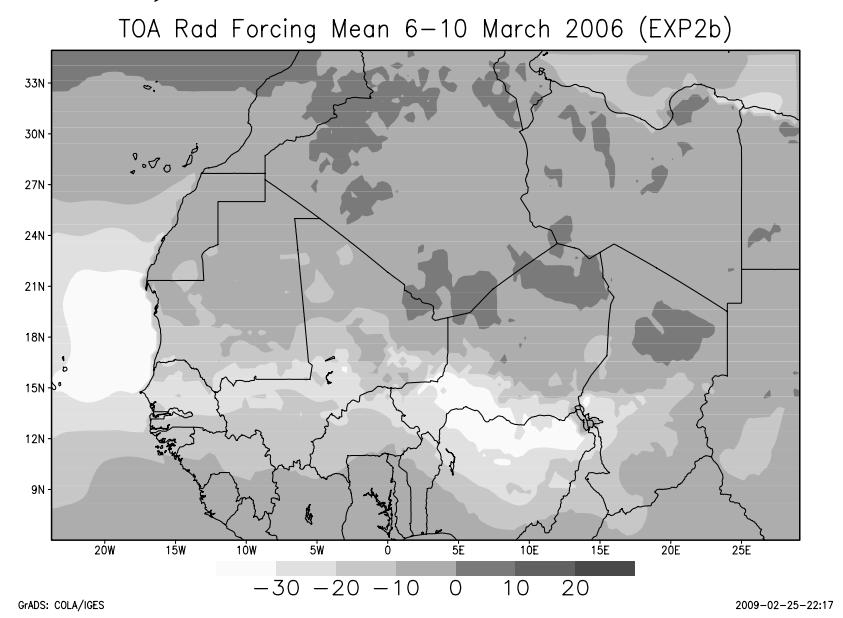

GrAOS: COLA/IGES

Figure 16. Shortwave radiative forcing at top of the atmosphere $\left(\mathrm{Wm}^{-2}\right)$. (a) Mean (6-11 March 2006) EXP1, (b) instantaneous 1200 UTC March 8 EXP1, (c) same as Figure 16a but for EXP2, (d) same as Figure 16b but for EXP2, (e) same as Figure 16a but for EXP2b, and (f) same as Figure 16b but for EXP2b. 


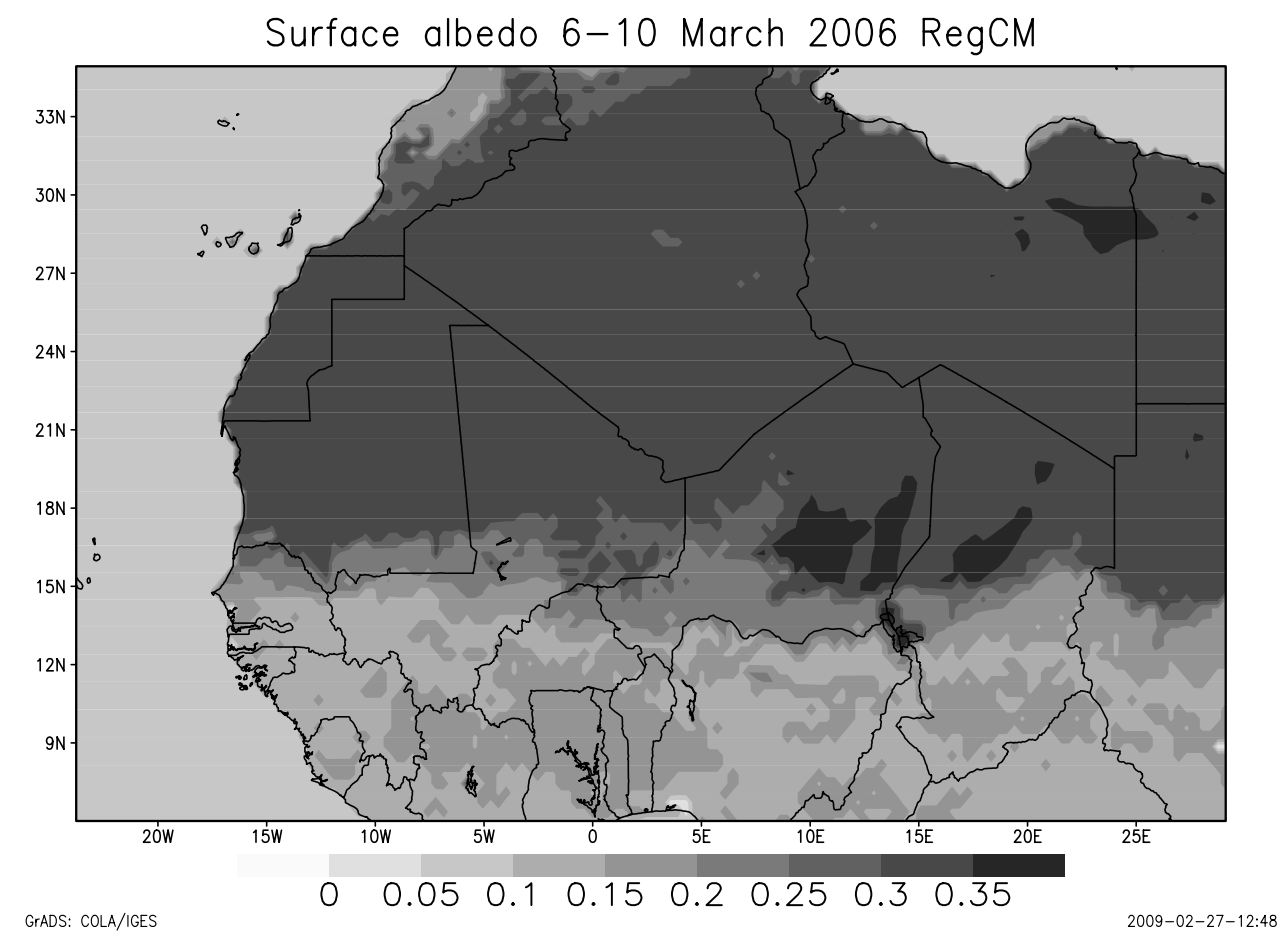

Figure 17. Time-averaged surface albedo values from RegCM.

represents reasonably well many of the key features of the meteorology of the cold surge, although for dust studies it is interesting to note that near-surface wind speeds are substantially underestimated. In this regard, the model might benefit from higher vertical resolution, especially in the boundary layer and alternative boundary layer parameterization to improve representation of turbulent fluxes in the lowest layers. Despite surface wind speed errors dust mobilization in the model is extensive. However, when using the predefined soil textures and hence aggregate size distributions, a number of active dust sources are not reproduced by the model. Accurate description of soil characteristics in remote, poorly observed regions, is a widely acknowledged problem in dust modeling, and one which has been previously addressed through specification of preferential dust source regions. In this case we apply a new dust source activation map defined from SEVIRI observations to define all those model cells which are "potential" dust sources [Schepanski et al., 2007]. The results show a clear improvement in terms of the space/time structure of dust emission and transport. Quantitative comparison of modeled AOT is problematic owing to lack of observations over the Sahara.Nevertheless, for the present work, there is considerable qualitative and quantitative evidence that the experiment with revised soil characteristics provides improvements in estimated AOT. The modified soil characteristics increases simulated AOT by about a factor of about 2, which is not unreasonable given the rather low dust loading reported for RegCM3 in a model intercomparison project by Todd et al. [2008a]. The results suggest that in the absence of truly accurate soil maps at high resolution, further refinements to the dust source activation map and its implementation in dust models can lead to useful improvements in simulation of dust processes and may lead to improved dust forecast accuracy. However, further evalu- ation of long-term model runs is required. In addition, the recent development of techniques to measure aerosol properties over bright-reflecting surfaces (i.e., the Deep Blue algorithm on SeaWiFS and MODIS instruments [Hsu et al., 2004]), will provide a solid evidence of the accuracy of models.

[30] Estimates of shortwave radiative forcing are derived and highlight the substantial cooling effect dust events can produce at the surface, with a normalized RF of about $-132-149 \mathrm{~W} \mathrm{~m}^{-2}$ per unit AOT. At the top of atmosphere the SW RF is sensitive to surface albedo with a domain average of about $-10 \mathrm{~W} \mathrm{~m}^{-2}$ per unit in this study. The top of atmosphere SW RF is positive over desert surfaces even for highly reflective aerosols owing to the high surface albedo in the model. It must be borne in mind that the model albedo fields do not represent the true spatial variability of surface albedo over the Sahara. Clearly the absolute magnitude of model simulated RF depends also on AOT and with the revised soil texture data set the RF is about twice the magnitude simulated using the default model configuration. Unfortunately, so far the model does not reproduce radiative forcing in the long wave spectrum, so the magnitude of the absorbing pattern on the infrared cannot be evaluated. Accordingly, further work is required to improve the soil data sets in dust models, as well as surface albedo, boundary layer meteorology and the specification of dust physical and optical properties as previous studies have indicated. These are likely to vary between different source regions across the Sahara such that further field studies are required to constrain our estimates of these parameters in model simulations.

[31] Acknowledgments. The authors thank Fabien Solmon and Ashraf Zakey for their helpful advice during this work. WMO weather station data were obtained from the Weather Underground (www.wunderground.com). 


\section{References}

Albrecht, B. A. (1989), Aerosols, cloud microphysics, and fractional cloudiness, Science, 245(4923), 1227-1230, doi:10.1126/science.245.4923.1227.

Alfaro, S. C., and L. Gomes (2001), Modeling mineral aerosol production by wind erosion: Emission intensities and aerosol size distributions in source areas, J. Geophys. Res., 106(D16), 18,075-18,084, doi:10.1029/ 2000JD900339.

Bellouin, N., A. Jones, J. Haywood, and S. A. Christopher (2008), Updated estimate of aerosol direct radiative forcing from satellite observations and comparison against the Hadley Centre climate model, J. Geophys. Res., 113, D10205, doi:10.1029/2007JD009385.

Berthier, S., P. Chazette, P. Couvert, J. Pelon, F. Dulac, F. Thieuleux, C. Moulin, and T. Pain (2006), Desert dust aerosol columnar properties over ocean and continental Africa from Lidar in-Space Technology Experiment (LITE) and Meteosat synergy, J. Geophys. Res., 111, D21202, doi:10.1029/2005JD006999.

Bey, I., D. J. Jacob, R. M. Yantosca, J. A. Logan, B. D. Field, A. M. Fiore, Q. B. Li, H. G. Y. Liu, L. J. Mickley, and M. G. Schultz (2001), Global modeling of tropospheric chemistry with assimilated meteorology: Model description and evaluation, J. Geophys. Res., 106(D19), 23,073-23,095, doi:10.1029/2001JD000807

Bothwell, G. W., E. G. Hansen, R. E. Vargo, and K. C. Miller (2002), The Multi-angle Imaging SpectroRadiometer science data system, its products, tools, and performance, IEEE Trans. Geosci. Remote Sens., 40(7), 1467-1476, doi:10.1109/TGRS.2002.801152.

Bouet, C., G. Cautenet, R. Washington, M. C. Todd, B. Laurent, B. Marticorena, and G. Bergametti (2007), Mesoscale modeling of aeolian dust emission during the BoDEx 2005 experiment, Geophys. Res. Lett., 34, L07812, doi:10.1029/2006GL029184.

Cautenet, G., F. Guillard, B. Marticorena, G. Bergametti, F. Dulac, and J. Edy (2000), Modelling of a Saharan dust event, Meteorol. Z., 9(4), 221-230.

Christopher, S. A., P. Gupta, J. Haywood, and G. Greed (2008), Aerosol optical thicknesses over North Africa: 1. Development of a product for model validation using Ozone Monitoring Instrument, Multiangle Imaging Spectroradiometer, and Aerosol Robotic Network, J. Geophys. Res., 113, D00C04, doi:10.1029/2007JD009446.

Cotton, W. R., et al. (2003), RAMS 2001: Current status and future directions, Meteorol. Atmos. Phys., 82(1-4), 5-29, doi:10.1007/s00703-0010584-9.

Dickinson, R. E., A. Henderson-Sellers, and P. J. Kennedy (1993), Biosphere-Atmosphere Transfer Scheme (BATS) version $1 E$ as coupled to the NCAR Community Climate Model, NCAR Tech. Note TN387+STR, 72 pp., Nat. Cent. for Atmos. Res, Boulder, Colo.

Ding, Y. H., X. L. Shi, Y. M. Liu, Y. Liu, Q. Q. Li, F. F. Qian, Q. Q. Miao, Q. Q. Zhai, and K. Gao (2006), Multi-year simulations and experimental seasonal predictions for rainy seasons in China by using a nested regional climate model (RegCM_NCC). Part I: Sensitivity study, Adv. Atmos. Sci., 23(3), 323-341, doi:10.1007/s00376-006-0323-8.

Dubovik, O., A. Smirnov, B. N. Holben, M. D. King, Y. J. Kaufman, T. F. Eck, and I. Slutsker (2000), Accuracy assessments of aerosol optical properties retrieved from Aerosol Robotic Network (AERONET) Sun and sky radiance measurements, J. Geophys. Res., 105(D8), 9791-9806, doi:10.1029/2000JD900040.

Dubovik, O., B. Holben, T. F. Eck, A. Smirnov, Y. J. Kaufman, M. D. King, D. Tanre, and I. Slutsker (2002), Variability of absorption and optical properties of key aerosol types observed in worldwide locations, J. Atmos. Sci., 59(3), 590-608, doi:10.1175/1520-0469(2002)059< 0590: $\operatorname{VOAAOP}>2.0 . \mathrm{CO} ; 2$.

Engelstaedter, S., and R. Washington (2007), Atmospheric controls on the annual cycle of North African dust, J. Geophys. Res., 112, D03103, doi:10.1029/2006JD007195.

Forster, P., et al. (2007), Changes in atmospheric constituents and in radiative forcing, in Climate Change 2007: The Physical Science Basis. Contribution of Working Group I to the Fourth Assessment Report of the Intergovernmental Panel on Climate Change, edited by S. Solomon et al., pp. 129-234, Cambridge Univ. Press, Cambridge, U. K.

Fouquart, Y., B. Bonnel, G. Brogniez, J. C. Buriez, L. Smith, J. J. Morcrette, and A. Cerf (1987), Observations of Saharan aerosols: Results of Eclats Field Experiment. 2. Broad-band radiative characteristics of the aerosols and vertical radiative flux divergence, J. Clim. Appl. Meteorol., 26(1), 3852, doi:10.1175/1520-0450(1987)026<0038:OOSARO>2.0.CO;2.

Gao, X. J., Y. Luo, W. T. Lin, Z. C. Zhao, and F. Giorgi (2003), Simulation of effects of land use change on climate in China by a regional climate model, Adv. Atmos. Sci., 20(4), 583-592, doi:10.1007/BF02915501.

Ghan, S. J., and S. E. Schwartz (2007), Aerosol properties and processes: A path from field and laboratory measurements to global climate models, Bull. Am. Meteorol. Soc., 88(7), 1059-1083, doi:10.1175/BAMS-88-71059.

Ginoux, P, M. Chin, I. Tegen, J. M. Prospero, B. Holben, O. Dubovik, and S. J. Lin (2001), Sources an utions of dust aerosols simulated with the GOCART model, J. Geophys. Res., 106(D17), 20,255-20,273, doi:10.1029/2000JD000053.

Giorgi, F., and C. Shields (1999), Tests of precipitation parameterizations available in latest version of NCAR regional climate model (RegCM) over continental United States, J. Geophys. Res., 104(D6), 6353-6375, doi:10.1029/98JD01164.

Giorgi, F., P. H. Whetton, R. G. Jones, J. H. Christensen, L. O. Mearns, B. Hewitson, H. vonStorch, R. Francisco, and C. Jack (2001), Emerging patterns of simulated regional climatic changes for the 21 st century due to anthropogenic forcings, Geophys. Res. Lett., 28(17), 3317-3320, doi:10.1029/2001GL013150.

Greed, G., J. M. Haywood, S. Milton, A. Keil, S. Christopher, P. Gupta, and E. J. Highwood (2008), Aerosol optical depths over North Africa: 2. Modeling and model validation, J. Geophys. Res., 113, D00C05, doi:10.1029/2007JD009457.

Grigorov, I., and G. Kolarov (2007), Measurements of atmospheric parameters using aerosol lidar, J. Optoelectron. Adv. Mater., 9(11), 35493552 .

Grini, A., P. Tulet, and L. Gomes (2006), Dusty weather forecasts using the MesoNH mesoscale atmospheric model, J. Geophys. Res., 111, D19205, doi:10.1029/2005JD007007.

Haywood, J., and O. Boucher (2000), Estimates of the direct and indirect radiative forcing due to tropospheric aerosols: A review, Rev. Geophys., 38(4), 513-543, doi:10.1029/1999RG000078

Haywood, J., P. Francis, S. Osborne, M. Glew, N. Loeb, E. Highwood, D. Tanre, G. Myhre, P. Formenti, and E. Hirst (2003), Radiative properties and direct radiative effect of Saharan dust measured by the C-130 aircraft during SHADE: 1. Solar spectrum, J. Geophys. Res., 108(D18), 8577, doi:10.1029/2002JD002687.

Heinold, B., J. Helmert, O. Hellmuth, R. Wolke, A. Ansmann, B. Marticorena, B. Laurent, and I. Tegen (2007), Regional modeling of Saharan dust events using LM-MUSCAT: Model description and case studies, J. Geophys. Res., 112, D11204, doi:10.1029/2006JD007443.

Helmert, J., B. Heinold, I. Tegen, O. Hellmuth, and M. Wendisch (2007), On the direct and semidirect effects of Saharan dust over Europe: A modeling study, J. Geophys. Res., 112, D13208, doi:10.1029/ 2006JD007444.

Herman, J. R., P. K. Bhartia, O. Torres, C. Hsu, C. Seftor, and E. Celarier (1997), Global distribution of UV-absorbing aerosols from Nimbus 7/ TOMS data, J. Geophys. Res., 102(D14), 16,911-16,922, doi:10.1029/ 96JD03680.

Hess, M., P. Koepke, and I. Schult (1998), Optical properties of aerosols and clouds: The software package OPAC, Bull. Am. Meteorol. Soc., $79(5), 831-844$, doi: $10.1175 / 1520-0477(1998) 079<$ 0831:OPOAAC $>2.0 . \mathrm{CO} ; 2$.

Holben, B. N., et al. (1998), AERONET-A federated instrument network and data archive for aerosol characterization, Remote Sens. Environ., 66(1), 1-16, doi:10.1016/S0034-4257(98)00031-5.

Holtslag, A. A. M., and B. A. Boville (1993), Local versus nonlocal boundarylayer diffusion in a global climate model, J. Clim., 6, 1825-1842, doi:10.1175/1520-0442(1993)006<1825:LVNBLD>2.0.CO;2.

Hsu, N. C., S. C. Tsay, M. D. King, and J. R. Herman (2004), Aerosol properties over bright-reflecting source regions, IEEE Trans. Geosci. Remote Sens., 42(3), 557-569, doi:10.1109/TGRS.2004.824067.

Jickells, T. D., et al. (2005), Global iron connections between desert dust, ocean biogeochemistry, and climate, Science, 308(5718), 67-71, doi: $10.1126 /$ science. 1105959.

Kalu, A. E. (1979), The African dust plume: Its characteristics and propagation across West Africa in winter, in Saharan Dust: Mobilization, Transport, Deposition, edited by C. Morales, pp. 95-118, John Wiley, Hoboken, N. J.

Kaufman, Y. J., D. Tanre, O. Dubovik, A. Karnieli, and L. A. Remer (2001), Absorption of sunlight by dust as inferred from satellite and ground-based remote sensing, Geophys. Res. Lett., 28(8), 1479-1482, doi:10.1029/2000GL012647.

Kaufman, Y. J., I. Koren, L. A. Remer, D. Rosenfeld, and Y. Rudich (2005a), The effect of smoke, dust, and pollution aerosol on shallow cloud development over the Atlantic Ocean, Proc. Natl. Acad. Sci. U. S. A., 102(32), 11,207-11,212, doi:10.1073/pnas.0505191102.

Kaufman, Y. J., I. Koren, L. A. Remer, D. Tanre, P. Ginoux, and S. Fan (2005b), Dust transport and deposition observed from the Terra-Moderate Resolution Imaging Spectroradiometer (MODIS) spacecraft over the Atlantic Ocean, J. Geophys. Res., 110, D10S12, doi:10.1029/ 2003JD004436.

Kiehl, J. T., J. J. Hack, G. B. Bonan, B. A. Boville, D. L. Williamson, and P. J. Rasch (1998), The National Center for Atmospheric Research Community Climate Model: CCM3, J. Clim., 11(6), 1131-1149, doi:10.1175/ 1520-0442(1998)011<1131:TNCFAR $>2.0$. CO;2.

King, M. D., Y. J. Kaufman, W. P. Menzel, and D. Tanre (1992), Remotesensing of cloud, aerosol, and water-vapor properties from the Moderate 
Resolution Imaging Spectrometer (MODIS), IEEE Trans. Geosci. Remote Sens., 30(1), 2-27, doi:10.1109/36.124212.

King, M. D., Y. J. Kaufman, D. Tanre, and T. Nakajima (1999), Remote sensing of tropospheric aerosols from space: Past, present, and future, Bull. Am. Meteorol. Soc., 80(11), 2229-2259, doi:10.1175/15200477(1999)080<2229:RSOTAF>2.0.CO;2.

Kinne, S., et al. (2003), Monthly averages of aerosol properties: A global comparison among models, satellite data, and AERONET ground data, J. Geophys. Res., 108(D20), 4634, doi:10.1029/2001JD001253.

Knippertz, P., and A. H. Fink (2006), Synoptic and dynamic aspects of an extreme springtime Saharan dust outbreak, Q. J. R. Meteorol. Soc., 132(617), 1153-1177, doi:10.1256/qj.05.109

Koren, I., Y. J. Kaufman, R. Washington, M. Todd, Y. Rudich, J. V. Martins, and D. Rosenfeld (2006), The Bodélé depression: A single spot in the Sahara that provides most of the mineral dust to the Amazon forest, Environ. Res. Lett., 1, 014005, doi:10.1088/1748.

Legrand, M, A. Plana-Fattori, and C. N'doume (2001), Satellite detection of dust using the IR imagery of Meteosat: 1 . Infrared difference dust index, J. Geophys. Res., 106(D16), 18,251-18,274.

Léon, J. F., D. Tanré, J. Pelon, Y. J. Kaufman, J. M. Haywood, and B. Chatenet (2003), Profiling of a Saharan dust outbreak based on a synergy between active and passive remote sensing, J. Geophys. Res., 108(D18), 8575, doi:10.1029/2002JD002774.

Liao, H., and J. H. Seinfeld (1998), Effect of clouds on direct aerosol radiative forcing of climate, J. Geophys. Res., 103(D4), 3781-3788, doi:10.1029/97JD03455.

Liu, Y. Q. (2005), Atmospheric response and feedback to radiative forcing from biomass burning in tropical South America, Agric. For. Meteorol., 133(1-4), 40-53, doi:10.1016/j.agrformet.2005.03.011.

Luo, C., N. M. Mahowald, N. Meskhidze, Y. Chen, R. L. Siefert, A. R. Baker, and A. M. Johansen (2005), Estimation of iron solubility from observations and a global aerosol model, J. Geophys. Res., 110, D23307, doi:10.1029/ 2005JD006059.

Mahowald, N. M., A. R. Baker, G. Bergametti, N. Brooks, R. A. Duce, T. D. Jickells, N. Kubilay, J. M. Prospero, and I. Tegen (2005), Atmospheric global dust cycle and iron inputs to the ocean, Global Biogeochem. Cycles, 19, GB4025, doi:10.1029/2004GB002402.

Mahowald, N. M., J. A. Ballantine, J. Feddema, and N. Ramankutty (2007), Global trends in visibility: Implications for dust sources, Atmos. Chem. Phys., 7, 3309-3339.

Marticorena, B., and G. Bergametti (1995), Modeling the atmospheric dust cycle: 1. Design of a soil-derived dust emission scheme, J. Geophys. Res., 100(D8), 16,415-16,430, doi:10.1029/95JD00690.

Matthews, E. (1984), Prescription of land-surface boundary conditions in GISS GCM II: A simple method based on high resolution vegetation data bases, NASA TM-86096, 21 pp., NASA Goddard Space Flight Cent., Greenbelt, Md.

Miller, R. L., and I. Tegen (1999), Radiative forcing of a tropical direct circulation by soil dust aerosols, J. Atmos. Sci., 56(14), 2403-2433, doi:10.1175/1520-0469(1999)056<2403:RFOATD $>2.0 . C O ; 2$

Milton, S. F., G. Greed, M. E. Brooks, J. Haywood, B. Johnson, R. P. Allan, A. Slingo, and W. M. F. Grey (2008), Modeled and observed atmospheric radiation balance during the West African dry season: Role of mineral dust, biomass burning aerosol, and surface albedo, J. Geophys. Res., 113 , D00C02, doi:10.1029/2007JD009741.

Myhre, G., A. Grini, J. M. Haywood, F. Stordal, B. Chatenet, D. Tanre, J. K. Sundet, and I. S. A. Isaksen (2003), Modeling the radiative impact of mineral dust during the Saharan Dust Experiment (SHADE) campaign, J. Geophys. Res., 108(D18), 8579, doi:10.1029/2002JD002566.

Nickovic, S., G. Kallos, A. Papadopoulos, and O. Kakaliagou (2001), A model for prediction of desert dust cycle in the atmosphere, J. Geophys. Res., 106(D16), 18,113-18,129, doi:10.1029/2000JD900794.

Penner, J. E., R. J. Charlson, J. M. Hales, N. S. Laulainen, R. Leifer, T. Novakov, J. Ogren, L. F. Radke, S. E. Schwartz, and L. Travis (1994), Quantifying and minimizing uncertainty of climate forcing by anthropogenic aerosols, Bull. Am. Meteorol. Soc., 75(3), 375-400, doi:10.1175 1520-0477(1994)075<0375:QAMUOC $>2.0 . C O ; 2$.

Pérez, C., S. Nickovic, G. Pejanovic, J. M. Baldasano, and E. Özsoy (2006), Interactive dust-radiation modeling: A step to improve weather forecasts, J. Geophys. Res., 111, D16206, doi:10.1029/2005JD006717.

Prospero, J. M., P. Ginoux, O. Torres, S. E. Nicholson, and T. E. Gill (2002), Environmental characterization of global sources of atmospheric soil dust identified with the Nimbus 7 Total Ozone Mapping Spectrometer (TOMS) absorbing aerosol product, Rev. Geophys., 40(1), 1002, doi:10.1029/2000RG000095.

Qian, Y., and F. Giorgi (1999), Interactive coupling of regional climate and sulfate aerosol models over eastern Asia, J. Geophys. Res., 104(D6), 6477-6499, doi:10.1029/98JD02347.

Qian, Y., F. Giorgi, Y. Huang, W. Chameides, and C. Luo (2001), Regional simulation of anthropogenic sulfur over East Asia and its sensitivity to model parameters, Tellus, Ser. B, 53(2), 171-191, doi:10.1034/j.16000889.2001.d01-14.x.

Redelsperger, J. L., C. D. Thorncroft, A. Diedhiou, T. Lebel, D. J. Parker, and J. Polcher (2006), African monsoon multidisciplinary analysis: An international research project and field campaign, Bull. Am. Meteorol. Soc., 87(12), 1739-1746, doi:10.1175/BAMS-87-12-1739.

Reid, J. S., et al. (2003), Analysis of measurements of Saharan dust by airborne and ground-based remote sensing methods during the Puerto Rico Dust Experiment (PRIDE), J. Geophys. Res., 108(D19), 8586, doi:10.1029/2002JD002493.

Schepanski, K., I. Tegen, B. Laurent, B. Heinold, and A. Macke (2007), A new Saharan dust source activation frequency map derived from MSGSEVIRI IR-channels, Geophys. Res. Lett., 34, L18803, doi:10.1029/ 2007GL030168.

Schmetz, J., P. Pili, S. Tjemkes, D. Just, J. Kerkmann, S. Rota, and A. Ratier (2002), An introduction to Meteosat Second Generation (MSG), Bull. Am Meteorol. Soc., 83(7), 977-992, doi:10.1175/1520-0477(2002)083< 0977:AITMSG>2.3.CO;2.

Seth, A., and F. Giorgi (1998), The effects of domain choice on summer precipitation simulation and sensitivity in a regional climate model, J. Clim., 11(10), 2698-2712, doi:10.1175/1520-0442(1998)011<2698:TEODCO> 2.0.CO;2.

Shao, Y. (2000), Physics and Modelling of Wind Erosion, Kluwer Acad., Dordrecht, Netherlands.

Slingo, A., et al. (2006), Observations of the impact of a major Saharan dust storm on the atmospheric radiation balance, Geophys. Res. Lett., 33, L24817, doi:10.1029/2006GL027869.

Sokolik, I. N., and O. B. Toon (1996), Direct radiative forcing by anthropogenic airborne mineral aerosols, Nature, 381(6584), 681-683, doi:10.1038/381681a0.

Sokolik, I. N., D. M. Winker, G. Bergametti, D. A. Gillette, G. Carmichael, Y. J. Kaufman, L. Gomes, L. Schuetz, and J. E. Penner (2001), Introduction to special section: Outstanding problems in quantifying the radiative impacts of mineral dust, J. Geophys. Res., 106(D16), 18,015-18,027, doi:10.1029/2000JD900498.

Solmon, F., F. Giorgi, and C. Liousse (2006), Aerosol modelling for regional climate studies: Application to anthropogenic particles and evaluation over a European/African domain, Tellus, Ser. B, 58(1), 51-72, doi:10.1111/j.1600-0889.2005.00155.x.

Stier, P., et al. (2005), The aerosol-climate model ECHAM5-HAM, Atmos Chem. Phys., 5, 1125-1156.

Stone, M. C., R. H. Hotchkiss, C. M. Hubbard, T. A. Fontaine, L. O. Mearns, and J. G. Arnold (2001), Impacts of climate change on Missour River Basin water yield, J. Am. Water Resour. Assoc., 37(5), 1119-1129, doi:10.1111/j.1752-1688.2001.tb03626.x.

Swap, R., M. Garstang, S. Greco, R. Talbot, and P. Kallberg (1992), Saharan dust in the Amazon Basin, Tellus, Ser. B, 44(2), 133-149, doi:10.1034 j.1600-0889.1992.t01-1-00005.x.

Tanré, D., J. Haywood, J. Pelon, J. F. Léon, B. Chatenet, P. Formenti, P. Francis, P. Goloub, E. J. Highwood, and G. Myhre (2003), Measurement and modeling of the Saharan dust radiative impact: Overview of the Saharan Dust Experiment (SHADE), J. Geophys. Res., 108(D18), 8574 , doi:10.1029/2002JD003273.

Tegen, I. (2003), Modeling the mineral dust aerosol cycle in the climate system, Quat. Sci. Rev., 22(18-19), 1821-1834, doi:10.1016/S02773791(03)00163-X

Tegen, I., and R. Miller (1998), A general circulation model study on the interannual variability of soil dust aerosol, J. Geophys. Res., 103(D20), 25,975-25,995, doi:10.1029/98JD02345.

Tegen, I., D. Koch, A. A. Lacis, and M. Sato (2000), Trends in tropospheric aerosol loads and corresponding impact on direct radiative forcing between 1950 and 1990: A model study, J. Geophys. Res., 105(D22), 26,971-26,989, doi:10.1029/2000JD900280.

Teller, A., and Z. Levin (2006), The effects of aerosols on precipitation and dimensions of subtropical clouds: A sensitivity study using a numerical cloud model, Atmos. Chem. Phys., 6, 67-80.

Todd, M. C., R. Washington, J. V. Martins, O. Dubovik, G. Lizcano, S. M'Bainayel, and S. Engelstaedter (2007), Mineral dust emission from the Bodélé Depression, northern Chad, during BoDEx 2005, J. Geophys. Res., 112, D06207, doi:10.1029/2006JD007170.

Todd, M. C., et al. (2008a), Quantifying uncertainty in estimates of mineral dust flux: An intercomparison of model performance over the Bodéle Depression, northern Chad, J. Geophys. Res., 113, D24107, doi:10.1029/2008JD010476.

Todd, M. C., R. Washington, S. Raghavan, G. Lizcano, and P. Knippertz (2008b), Regional model simulations of the Bodele low-level jet of northern Chad during the Bodélé Dust Experiment (BoDEx 2005), J. Clim., 21(5), 995-1012, doi:10.1175/2007JCLI1766.1. 
Tompkins, A. M., C. Cardinali, J. J. Morcrette, and M. Rodwell (2005), Influence of aerosol climatology on forecasts of the African Easterly Jet, Geophys. Res. Lett., 32, L10801, doi:10.1029/2004GL022189.

Torres, O., P. K. Bhartia, J. R. Herman, Z. Ahmad, and J. Gleason (1998), Derivation of aerosol properties from satellite measurements of backscattered ultraviolet radiation: Theoretical basis, J. Geophys. Res., 103(D14), 17,099-17,110, doi:10.1029/98JD00900.

Torres, O., A. Tanskanen, B. Veihelmann, C. Ahn, R. Braak, P. K. Bhartia, P. Veefkind, and P. Levelt (2007), Aerosols and surface UV products from Ozone Monitoring Instrument observations: An overview, J. Geophys. Res., 112, D24S47, doi:10.1029/2007JD008809.

Tulet, P., M. Mallet, V. Pont, J. Pelon, and A. Boone (2008), The 7-13 March 2006 dust storm over West Africa: Generation, transport, and vertical stratification, J. Geophys. Res., 113, D00C08, doi:10.1029/ 2008JD009871.

Twomey, S. (1977), Influence of pollution on shortwave albedo of clouds, J. Atmos. Sci., 34(7), 1149-1152, doi:10.1175/1520-0469(1977)034< 1149:TIOPOT $>2.0 . \mathrm{CO} ; 2$

Twomey, S. (1991), Aerosols, clouds and radiation, Atmos. Environ., Part $A, 25(11), 2435-2442$, doi:10.1016/0960-1686(91)90159-5.

Uno, I., et al. (2006), Dust model intercomparison (DMIP) study over Asia: Overview, J. Geophys. Res., 111, D12213, doi:10.1029/2005JD006575.

Washington, R., and M. C. Todd (2005), Atmospheric controls on mineral dust emission from the Bodélé Depression, Chad: The role of the low level jet, Geophys. Res. Lett., 32, L17701, doi:10.1029/2005GL023597.

Washington, R., M. Todd, N. J. Middleton, and A. S. Goudie (2003), Duststorm source areas determined by the total ozone monitoring spectrometer and surface observations, Ann. Assoc. Am. Geogr., 93(2), 297-313, doi:10.1111/1467-8306.9302003.

Washington, R., M. C. Todd, S. Engelstaedter, S. Mbainayel, and F. Mitchell (2006), Dust and the low-level circulation over the Bodélé Depression,
Chad: Observations from BoDEx 2005, J. Geophys. Res., 111, D03201, doi:10.1029/2005JD006502.

Woodward, S. (2001), Modeling the atmospheric life cycle and radiative impact of mineral dust in the Hadley Centre climate model, J. Geophys. Res., 106(D16), 18,155-18,166, doi:10.1029/2000JD900795.

Yang, Z. L., and R. E. Dickinson (1996), Description of the biosphereatmosphere transfer scheme (BATS) for the soil moisture workshop and evaluation of its performance, Global Planet. Change, 13(1-4), 117-134, doi:10.1016/0921-8181(95)00041-0.

Zakey, A. S., F. Solmon, and F. Giorgi (2006), Implementation and testing of a desert dust module in a regional climate model, Atmos. Chem. Phys., 6, 4687-4704.

Zender, C. S., H. S. Bian, and D. Newman (2003a), Mineral Dust Entrainment and Deposition (DEAD) model: Description and 1990s dust climatology, J. Geophys. Res., 108(D14), 4416, doi:10.1029/2002JD002775.

Zender, C. S., D. Newman, and O. Torres (2003b), Spatial heterogeneity in aeolian erodibility: Uniform, topographic, geomorphic, and hydrologic hypotheses, J. Geophys. Res., 108(D17), 4543, doi:10.1029/ 2002JD003039.

Zender, C. S., R. Miller, and I. Tegen (2004), Quantifying mineral dust mass budgets: Terminology, constraints, and current estimates, Eos Trans. $A G U, 85(48), 509-512$, doi:10.1029/2004EO480002.

Zobler, L. (1986), A world soil file for global climate modelling, NASA TM 87802, 32 pp., NASA Goddard Space Flight Cent., Greenbelt, Md.

C. Cavazos and M. C. Todd, Department of Geography, University College London, Gower Street, London WC1E 6BT, UK. (ccavazos@geog. ucl.ac.uk)

K. Schepanski, Leibniz Institute for Tropospheric Research, Permoser Straße 15, D-04318, Leipzig, Germany. 